\title{
Exploring the atmospheric chemistry of nitrous acid (HONO) at a rural site in Southern China
}

\author{
X. Li ${ }^{1,2}$, T. Brauers ${ }^{2}$, R. Häseler ${ }^{2}$, B. Bohn ${ }^{2}$, H. Fuchs ${ }^{2}$, A. Hofzumahaus ${ }^{2}$, F. Holland ${ }^{2}$, S. Lou ${ }^{2,3, *}$, K. D. Lu ${ }^{1,2}$, \\ F. Rohrer ${ }^{2}$, M. Hu ${ }^{1}$, L. M. Zeng ${ }^{1}$, Y. H. Zhang ${ }^{1}$, R. M. Garland ${ }^{4, * *}$, H. Su $^{1,4}$, A. Nowak ${ }^{5, * * *}$, A. Wiedensohler ${ }^{5}$, \\ N. Takegawa ${ }^{6}$, M. Shao ${ }^{1}$, and A. Wahner ${ }^{2}$ \\ ${ }^{1}$ College of Environmental Sciences and Engineering, Peking University, Beijing, China \\ ${ }^{2}$ Institute for Energy and Climate Research, IEK-8, Research Center Jülich, Jülich, Germany \\ ${ }^{3}$ School of Environmental Science and Technology, Shanghai Jiaotong University, Shanghai, China \\ ${ }^{4}$ Max Planck Institute for Chemistry, Biogeochemistry Department, Mainz, Germany \\ ${ }^{5}$ Leibniz Institute for Tropospheric Research, Leipzig, Germany \\ ${ }^{6}$ Research Center for Advanced Science and Technology, University of Tokyo, Tokyo, Japan \\ *now at: Shanghai Academy of Environmental Sciences, Shanghai, China \\ *** now at: Natural Resources and the Environment, CSIR, Pretoria, South Africa \\ *** now at: Physikalisch Technische Bundesanstalt, Braunschweig, Germany
}

Correspondence to: T. Brauers (th.brauers@fz-juelich.de)

Received: 27 September 2011 - Published in Atmos. Chem. Phys. Discuss.: 11 October 2011

Revised: 23 January 2012 - Accepted: 25 January 2012 - Published: 8 February 2012

\begin{abstract}
We performed measurements of nitrous acid (HONO) during the PRIDE-PRD2006 campaign in the Pearl River Delta region $60 \mathrm{~km}$ north of Guangzhou, China, for 4 weeks in June 2006. HONO was measured by a LOPAP in-situ instrument which was setup in one of the campaign supersites along with a variety of instruments measuring hydroxyl radicals, trace gases, aerosols, and meteorological parameters. Maximum diurnal HONO mixing ratios of $1-5 \mathrm{ppb}$ were observed during the nights. We found that the nighttime build-up of HONO can be attributed to the heterogeneous $\mathrm{NO}_{2}$ to $\mathrm{HONO}$ conversion on ground surfaces and the $\mathrm{OH}+\mathrm{NO}$ reaction. In addition to elevated nighttime mixing ratios, measured noontime values of $\approx 200 \mathrm{ppt}$ indicate the existence of a daytime source higher than the $\mathrm{OH}+\mathrm{NO} \rightarrow \mathrm{HONO}$ reaction. Using the simultaneously recorded $\mathrm{OH}, \mathrm{NO}$, and $\mathrm{HONO}$ photolysis frequency, a daytime additional source strength of HONO $\left(P_{M}\right)$ was calculated to be $0.77 \mathrm{ppbh}^{-1}$ on average. This value compares well to previous measurements in other environments. Our analysis of $P_{M}$ provides evidence that the photolysis of $\mathrm{HNO}_{3}$ adsorbed on ground surfaces contributes to the $\mathrm{HONO}$ formation.
\end{abstract}

\section{Introduction}

Nitrous acid (HONO) is an important trace gas in the atmosphere due to its contribution to the cycles of nitrogen oxides $\left(\mathrm{NO}_{\mathrm{x}}\right)$ and hydrogen oxides $\left(\mathrm{HO}_{\mathrm{x}}\right)$ (Finlayson-Pitts and Pitts, 2000). The photolysis of HONO in the near ultraviolet spectral region $(320 \mathrm{~nm}<\lambda<400 \mathrm{~nm})$ :

$\mathrm{HONO}+h v \rightarrow \mathrm{OH}+\mathrm{NO}$

provides a daytime source of hydroxyl radicals $(\mathrm{OH})$ and nitrogen oxides (NO) independently from ozone photolysis and $\mathrm{NO}_{2}$ concentrations. This feature is even more important after HONO accumulates under dark or low light conditions.

Observations of HONO in the troposphere were performed at many locations over the last $30 \mathrm{yr}$. These measurements revealed concentrations from several ppts in remote and clean areas (e.g. Zhou et al., 2002, 2007; Beine et al., 2006; Ren et al., 2010) up to several ppbs in more polluted environments (e.g. Febo et al., 1996; Stutz et al., 2002; Kanaya et al., 2007; Su et al., 2008a; Yu et al., 2009). Due to photolysis, HONO exhibits a diurnal variation with minima during the day. The highest reported values occurred during nighttime in heavily polluted megacities like Santiago, Chile (Elshorbany et al., 2009), and Guangzhou, China (Qin et al., 2009). The level

Published by Copernicus Publications on behalf of the European Geosciences Union. 


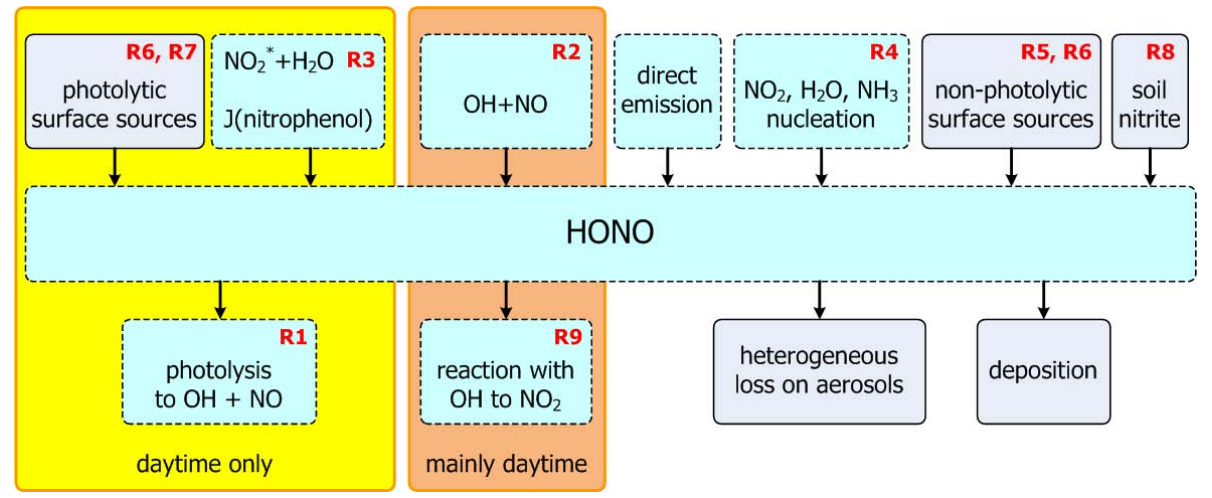

Fig. 1. Diagram of HONO budget in the troposphere. Boxes in light blue refers to gas phase reactions, while grey boxes refer to processes with various surfaces involved. Reactions in the yellow frame need solar radiation and thus only take place in daytime. When significant amount of $\mathrm{OH}$ radicals and $\mathrm{NO}$ exist, reactions in the light orange frame will also happen in night.

of $\mathrm{HONO}$ is related to the $\mathrm{NO}_{\mathrm{x}}$ levels during all of these field experiments, however this relation is highly variable as indicated by the $\mathrm{HONO}$ to $\mathrm{NO}_{\mathrm{x}}$ ratios determined in the above experiments, ranging from way below $1 \%$ to well above $10 \%$.

Despite the importance of HONO in atmospheric chemistry, the HONO budget in the troposphere is not well understood since both emissions, homogeneous and heterogeneous processes influence the gas phase concentration of HONO. Figure 1 depicts the different pathways of HONO formation and loss. Direct emissions of HONO have been accessed through tunnel experiments and car exhaust analysis; the emission ratios of $\mathrm{HONO} / \mathrm{NO}_{\mathrm{x}}$ are found to be $0.3-0.8 \%$ (Kurtenbach et al., 2001, and references therein). These values are generally much lower than that from the field observations, indicating that the atmospheric HONO is mostly secondarily formed.

The reverse reaction of Reaction (R1) is the most important homogeneous reaction forming HONO.

$\mathrm{OH}+\mathrm{NO} \stackrel{M}{\longrightarrow} \mathrm{HONO}$

This reaction plays a role mainly during daytime when $\mathrm{OH}$ and NO are high (e.g. Alicke et al., 2003). However, in regions with significant amount of nighttime $\mathrm{OH}$, e.g., Pearl River Delta in China (Lu et al., 2011), the contribution of Reaction (R2) to the nocturnal HONO formation might not be neglected. Li et al. (2008) found that the homogeneous reaction of photolytically excited $\mathrm{NO}_{2}$ with $\mathrm{H}_{2} \mathrm{O}$ can form $\mathrm{OH}$ and HONO.

$\mathrm{NO}_{2}+h v(\lambda>420 \mathrm{~nm}) \rightarrow \mathrm{NO}_{2}^{*}$

$\mathrm{NO}_{2}^{*}+\mathrm{H}_{2} \mathrm{O} \rightarrow \mathrm{OH}+\mathrm{HONO}$

But its reaction rate and yield are still under discussion (Carr et al., 2009) and this mechanism does not significantly contributes to the atmospheric HONO formation (Sörgel et al., 2011a; Wong et al., 2011; Amedro et al., 2011). Laboratory studies found that the photolysis of ortho-nitrophenols also leads to homogeneous HONO formation (Bejan et al., 2006). Although the estimated HONO formation rate of $100 \mathrm{ppth}^{-1}$ for $1 \mathrm{ppb}$ nitrophenols at overhead sun could be a significant fraction of the total HONO formation rate during daytime, the relevance of this mechanism needs to be validated through field measurements. Based on theoretical calculations, Zhang and Tao (2010) proposed a gas phase HONO formation pathway through the homogeneous nucleation of $\mathrm{NO}_{2}, \mathrm{H}_{2} \mathrm{O}$ and $\mathrm{NH}_{3}$.

$$
2 \mathrm{NO}_{2}(\mathrm{~g})+\mathrm{H}_{2} \mathrm{O}(\mathrm{g})+\mathrm{NH}_{3}(\mathrm{~g}) \rightarrow \mathrm{HONO}(\mathrm{g})+\mathrm{NH}_{4} \mathrm{NO}_{3}(\mathrm{~s})
$$

However, this reaction has not yet been tested by laboratory studies nor observed in field experiments.

Compared to the homogeneous HONO formation, heterogeneous formation of HONO on various surfaces is thought to be the most likely explanation of the observed high HONO concentrations. Laboratory studies revealed that $\mathrm{NO}_{2}$ can be converted to HONO on wet surfaces.

$\mathrm{NO}_{2}+\mathrm{NO}_{2}+\mathrm{H}_{2} \mathrm{O}_{\text {ads }} \stackrel{\text { surf }}{\longrightarrow} \mathrm{HONO}+\mathrm{HNO}_{3}$

However, the source strength of Reaction (R5) is not exactly known and depends on various parameters including the gas phase $\mathrm{NO}_{2}$ concentration, the surface water content, and the surface area density (Finlayson-Pitts et al., 2003). Laboratory studies also found a heterogeneous reduction of $\mathrm{NO}_{2}$ forming $\mathrm{HONO}$ on soot particles or surfaces containing organic substrates (Ammann et al., 1998, 2005; Kleffmann et al., 1999; Bröske et al., 2003; Aubin and Abbatt, 2007). The proposed mechanism of this redox HONO formation is

$\mathrm{NO}_{2}+\mathrm{HC}_{\text {red }} \stackrel{\text { surf }}{\longrightarrow} \mathrm{HONO}+\mathrm{HC}_{\mathrm{ox}}$

Reaction (R6) can be relevant for HONO formation under conditions of high $\mathrm{NO}_{2}$ and soot loadings, i.e. in plumes (Kleffmann et al., 1999). Following Akimoto et al. (1987) who reported that Reaction (R6) was photo-enhanced, a photosensitized $\mathrm{NO}_{2}$ reduction on organic surfaces has been observed 
recently in many studies as an effective pathway producing HONO (George et al., 2005; Stemmler et al., 2006). The production rate of HONO is a complex function of the actinic flux, the surface area density and gas phase $\mathrm{NO}_{2}$ concentration (Stemmler et al., 2007). At low $\mathrm{NO}_{2}$, the $\mathrm{HONO}$ production is linearly increasing with $\mathrm{NO}_{2}$; whilst the increase levels off when the $\mathrm{NO}_{2}$ concentration reaches a certain point. The same phenomenon is also found for the actinic flux. The rate of the photosensitized reaction was 1-2 orders of magnitude more efficient than the dark reaction (George et al., 2005).

Both laboratory studies and field observations found that $\mathrm{HONO}$ can also be heterogeneously formed through the photolysis of adsorbed nitric acid $\left(\mathrm{HNO}_{3}\right)$ and nitrate $\left(\mathrm{NO}_{3}^{-}\right)$at UV wavelengths (Zhou et al., 2002, 2003):

$\mathrm{HNO}_{3} / \mathrm{NO}_{3}^{-}+h v \rightarrow \mathrm{HONO} / \mathrm{NO}_{2}^{-}+\mathrm{O}$

It is still an open question why the $\mathrm{HNO}_{3}$-to-HONO conversion frequency necessary to explain the observed HONO production is orders of magnitude higher than the photolysis of $\mathrm{HNO}_{3}$ in the gas and liquid phase (Zhou et al., 2003; Rohrer et al., 2005). However, a new field study by Zhou et al. (2011) provided evidence for a daytime source of nitrous acid caused by the photolysis of nitric acid on forest canopies.

Recently, Su et al. (2011) illustrated that the soil nitrite, which is formed through the biological nitrification and denitrification processes, can be a prominent $\mathrm{HONO}$ source. The HONO formation is via the following reversible acid-base reaction and partitioning between air and the aqueous phase of humid soil:

$\mathrm{NO}_{2}^{-}(\mathrm{aq})+\mathrm{H}^{+}(\mathrm{aq}) \leftrightarrow \mathrm{HNO}_{2}(\mathrm{aq}) \leftrightarrow \mathrm{HONO}(\mathrm{g})$

Its HONO production rate depends on the nitrite concentration, the $\mathrm{pH}$ value, the water content and the temperature of the soil. Values from 2 to $5 \mathrm{pph} \mathrm{h}^{-1}$ were estimated for the field measurements in Xinken in Southern China, which can explain most HONO productions besides Reaction (R2) during daytime.

Compared to HONO formation, the loss processes of HONO are well understood. Besides Reaction (R1), HONO can be removed by reaction with $\mathrm{OH}$.

$\mathrm{HONO}+\mathrm{OH} \rightarrow \mathrm{H}_{2} \mathrm{O}+\mathrm{NO}_{2}$

Reactions (R1) and (R9) are well established and they determine the HONO lifetime during daytime. Under typical daytime conditions the HONO lifetime is in the order of 20 min. Other gas phase reactions of HONO, e.g. self reaction or reaction with $\mathrm{HNO}_{3}$, are not important under tropospheric conditions. Heterogeneous loss of HONO on various surfaces is too slow to be relevant in most cases (Stutz et al., 2002, and references therein). During night, the ma- jor HONO removal pathway is the dry deposition on ground surfaces (Trick, 2004), i.e.

$\frac{d[\mathrm{HONO}]}{d t}=\frac{\nu_{\mathrm{HONO}}^{\text {ground }} \times[\mathrm{HONO}]}{H}$

where $v_{\mathrm{HONO}}^{\text {ground }}$ is the deposition velocity of HONO and $H$ the height of the well-mixed layer. The reported value of $v_{\mathrm{HONO}}^{\text {ground }}$ ranges from 0.077 to $3 \mathrm{~cm} \mathrm{~s}^{-1}$ (Harrison and Kitto, 1994; Harrison et al., 1996; Spindler et al., 1999; Stutz et al., 2002).

The question of HONO budget is two-fold, a day and a night problem. Due to the absence of solar radiation and low concentration of $\mathrm{OH}$ radicals during night, it is well accepted that the nocturnal HONO is mainly formed by the heterogeneous conversion of $\mathrm{NO}_{2}$. Regardless the detailed chemical mechanisms, the strength of the $\mathrm{HONO}$ formation from $\mathrm{NO}_{2}$ can be expressed as the HONO conversion frequency $C_{\mathrm{HONO}}$ (Alicke et al., 2002, 2003),

$C_{\mathrm{HONO}}=\frac{\left[\mathrm{HONO}_{t_{2}}-\left[\mathrm{HONO}_{t_{1}}\right.\right.}{\left(t_{2}-t_{1}\right) \times \overline{\left[\mathrm{NO}_{2}\right]}}$

where $\overline{\left[\mathrm{NO}_{2}\right]}$ is the average $\mathrm{NO}_{2}$ mixing ratio in the time interval of $t_{2}-t_{1}$. In order to correct the effects of source emission and diffusion, complex scaling methods has been tested by $\mathrm{Su}$ et al. (2008a) during the calculation of $C_{\mathrm{HONO}}$. They found that values of $C_{\mathrm{HONO}}$ derived from using different scaling species or without applying scaling method do not show a big difference.

During daytime, recent field observations find that the HONO concentration is too high to be explained by the gas phase Reactions (R1), (R2) and (R9). Therefore, the daytime HONO budget was expanded by an additional production rate term $P_{M}$ (Su et al., 2008b).

$\frac{d[\mathrm{HONO}]}{d t}=$

$k_{\mathrm{OH}+\mathrm{NO}}[\mathrm{OH}][\mathrm{NO}]+P_{M}-\left(J_{\mathrm{HONO}}+k_{\mathrm{OH}+\mathrm{HONO}}[\mathrm{OH}]\right) \times[\mathrm{HONO}]$

Here we omitted the influence of direct emission, deposition, horizontal and vertical transport on the HONO concentration since their influence is relatively small compared to the gas phase reactions and can be neglected in Eq. (3). Under quasi stationary conditions, i.e. $d[\mathrm{HONO}] / d t \approx 0$, the additional production rate $P_{M}$ can be expressed by

$P_{M}=\left(J_{\mathrm{HONO}}+k_{\mathrm{OH}+\mathrm{HONO}}[\mathrm{OH}]\right) \times[\mathrm{HONO}]-k_{\mathrm{OH}+\mathrm{NO}}[\mathrm{OH}][\mathrm{NO}]$

which also corresponds to an additional HONO concentration $[\mathrm{HONO}]_{M}$ calculated from from the difference of the measured HONO and the budget without $P_{M}$ :

$[\mathrm{HONO}]_{M}=[\mathrm{HONO}]-\frac{k_{\mathrm{OH}+\mathrm{NO}}[\mathrm{OH}][\mathrm{NO}]}{k_{\mathrm{HONO}+\mathrm{OH}}[\mathrm{OH}]+J_{\mathrm{HONO}}}$

which is equivalent to

$[\mathrm{HONO}]_{M}=\frac{P_{M}}{k_{\mathrm{HONO}+\mathrm{OH}}[\mathrm{OH}]+J_{\mathrm{HONO}}}$ 
For the first time Kleffmann et al. (2005) had a full set of OH, $\mathrm{NO}$, and photolysis frequency measurements simultaneously with HONO so they could directly derive $P_{M}$ for their measurements in a mixed deciduous forest in Germany. Their value of $0.55 \mathrm{ppbh}^{-1}$ exceeds the possible source by Reaction (R5) therefore indicating an additional source of HONO. Similar findings, using direct measurements of $\mathrm{HONO}, \mathrm{OH}$, $\mathrm{NO}$, and $J_{\mathrm{HONO}}$, were obtained by Acker et al. (2006b) and Wong et al. (2012).

With the fast economic growth, the Pearl River Delta (PRD) region in Southern China has been identified as one of the hot-spots of $\mathrm{NO}_{2}$ by satellite measurements (Richter et al., 2005). The first continuous HONO measurements in the PRD region was conducted by Su et al. $(2008 \mathrm{a}, \mathrm{b})$ at a non-urban site in XinKen $\left(22.61^{\circ} \mathrm{N}, 113.61^{\circ} \mathrm{E}\right)$. Besides the high nighttime HONO concentration (0.4-3.5 ppb) a surprisingly high daytime average of $1.2 \mathrm{ppb}$ was observed. However, due to the lack of measured key parameters (i.e. photolysis frequencies and $\mathrm{OH}$ ) and the low time resolution of their HONO measurement, the investigation of the daytime HONO chemistry by Su et al. (2008b) left some open questions. Here we present the HONO data recorded during the PRIDE-PRD2006 campaign. We performed 4 weeks of continuous HONO measurements at a rural site in PRD region by the LOPAP technique side-by-side to measurements of trace gases, $\mathrm{HO}_{\mathrm{x}}$ radicals, aerosol parameters and meteorological conditions. The contribution of $\mathrm{HONO}$ to the $\mathrm{HO}_{\mathrm{x}}$ production has been investigated and discussed by $\mathrm{Lu}$ et al. (2011). The relative contribution was found to be $8-28 \%$ during the campaign. In this study, we are focusing on the analysis of the HONO budget. The simultaneous measurements that are used for the identification and quantification of HONO sources and sinks are summarized in Table 1.

\section{Experiment}

\subsection{LOPAP instrument}

HONO was measured by LOPAP (long path absorption photometer) technique which was pioneered by Kleffmann and co-workers (Heland et al., 2001; Kleffmann et al., 2006). The instrument used in this study was a commercial version of the original instrument (QUMA GmbH, Wuppertal). Since the LOPAP instrument has been described in detail previously we give only a short outline. Ambient air is sampled into a sampling unit consisting of two stripping coils in series. Stripping solution of $100 \mathrm{~g}$ sulfanilamide and $11 \mathrm{HCl}(37 \%$ volume fraction) in 91 MilliQ water is pumped through the coils. HONO and any interfering species in the sampled air will dissolve in the liquid phase forming $\mathrm{NO}_{2}^{-}$followed by a rapid reaction of $\mathrm{NO}_{2}^{-}$forming a stable diazonium salt. Almost all HONO and a small fraction of interfering species are taken out by the first coil, while the second coil takes out the same amount of interfering species but has no HONO in it. After debubbling the remaining air, the formed diazonium salt solution of each coil is pumped from the sampling unit to the detection unit through a $2.5 \mathrm{~m}$ insolated Teflon tubing. Each solution is then reacted with a dye solution made by dissolving 1.6 g n-(1-naphthyl)-ethylenediaminedihydrochloride in 81 MilliQ water forming an azo dye. The concentration of the azo dye is monitored by a 2 channel optical absorption spectrometer which absorption cell consists of a $1.2 \mathrm{~m}$ long Teflon tubing (called Liquid Core Waveguide, LCW). Visible light from a white LED lamp (Lumileds, Typ: LUXEON V star white, LXHLLW6C) is focused into the tubing via fiber optics. At the opposite end of the LCW, the light is collected by a fiber and detected by the spectrometer. The absorption spectra are recorded on a computer for later data evaluation. All the processes above are continuously operated.

The sampled air flow and the liquid flow of the stripping solution was set to $11 \mathrm{~min}^{-1}$ and $0.28 \mathrm{ml} \mathrm{min}^{-1}$, respectively, and both were calibrated every third day during the campaign. Zero measurements by sampling zero air were done manually every $12 \mathrm{~h}$. With above settings, the sampling efficiency of HONO in the sampling unit was determined to be $99.93 \%$. The time resolution, detection limit and accuracy of the measurement was $5 \mathrm{~min}, 7 \mathrm{ppt}$ and $10 \%$, respectively.

\subsection{Measurement site and campaign setup}

The PRIDE-PRD2006 intensive campaign took place from 3 to 31 July 2006 in the Pearl River Delta (PRD) area in Southern China. Our measurements were conducted at the Back Garden (BG) supersite $\left(23.50^{\circ} \mathrm{N}, 113.03^{\circ} \mathrm{E}\right)$ which is about $60 \mathrm{~km}$ northwest of Guangzhou. The BG site is located near a water reservoir and is surrounded by farmland (peanuts, lychees, trees, small forests). It experienced little local emissions from traffic, but road and building construction as well as biomass and cable burning were occasionally observed within the surrounding area. The campaign was within the framework of the Program of Regional Integrated Experiments of Air Quality over the Pearl River Delta (PRIDE-PRD2006, Zhang et al., 2012). This program targets on understanding the formation mechanism of $\mathrm{O}_{3}$ and fine particulate matter within the densely populated PRD area.

The BG supersite was equipped with a comprehensive suite of atmospheric measurements (e.g. Garland et al., 2008; Hofzumahaus et al., 2009; Li et al., 2010; Lou et al., 2010; Lu et al., 2011). On-site measurements used in this study are reported in Table 1 with their time resolutions and positions relative to the LOPAP. The sampling unit of the LOPAP was fixed on the top of the FZJ lab container housing the $\mathrm{HO}_{\mathrm{x}}$ ( $\mathrm{Lu}$ et al., 2011) and OH reactivity (Lou et al., 2010) instruments. The container was stacked on top of a second container hence the sampling height was $6 \mathrm{~m}$ above the ground. The detection unit (i.e. pumps, spectrometers etc.) was placed inside the lab container which was held at constant temperature. 
Table 1. Instrumentation at the Guangzhou backgarden supersite. The instruments listed here do only refer to data used in this study. For a comprehensive overview of all instruments participating see Hofzumahaus et al. (2009); Lou et al. (2010); Lu et al. (2011); the measured parameters are explained in the text.

\begin{tabular}{llcrlrl}
\hline Instrument & Parameter & Group & Time res. & Position & Distance $^{\text {a }}$ & Reference \\
\hline LOPAP & $\mathrm{HONO}$ & FZJ & $1 \mathrm{~min}$ & top of LIF container & - & this work \\
LIF $^{\mathrm{b}}$ & $\mathrm{OH}$ & FZJ & $1 \mathrm{~min}$ & top of LIF container & $1 \mathrm{~m}$ & Lu et al. (2011) \\
LP-LIF $^{\mathrm{c}}$ & $k_{\mathrm{OH}}$ & FZJ & $1 \mathrm{~min}$ & top of LIF container & $1 \mathrm{~m}$ & Lou et al. (2010) \\
CL $^{\mathrm{d}}$ & $\mathrm{NO}, \mathrm{NO}_{2}$ & $\mathrm{UT}$ & $1 \mathrm{~min}$ & hotel roof & $200 \mathrm{~m}$ & Takegawa et al. (2006) \\
SR $^{\mathrm{e}}$ & $J_{\mathrm{HONO}}, J_{\mathrm{NO}_{2}}, J_{\mathrm{HNO}_{3}}$ & FZJ & $1 \mathrm{~min}$ & hotel roof & $200 \mathrm{~m}$ & Bohn et al. (2008) \\
GAC-IC $^{\mathrm{f}}$ & $\mathrm{HNO}_{3}$ & PKU & $30 \mathrm{~min}$ & hotel roof & $200 \mathrm{~m}$ & Su et al. (2008b) \\
TDMPS-APS & $S_{\mathrm{a}}$ & IfT & $10 \mathrm{~min}$ & hotel roof & $200 \mathrm{~m}$ & Yue et al. (2010) \\
NEPH+PAS & $\sigma_{\mathrm{a}, 532}, \omega_{532}$ & MPIC & $2 \mathrm{~min}$ & hotel roof & $200 \mathrm{~m}$ & Garland et al. (2008) \\
MET $^{\mathrm{i}}$ & $\mathrm{RH}$ & PKU & $10 \mathrm{~min}$ & hump at LIF container & $20 \mathrm{~m}$ & Hofzumahaus et al. (2009) \\
\hline
\end{tabular}

${ }^{a}$ : horizontal distance from inlet to HONO sampling. The sampling height on top of the LIF container was $6 \mathrm{~m}$ less than on the hotel roof. ${ }^{b}:$ Laser Induced Florescence. $^{\mathrm{c}}:$ Laser-flash Photolysis Laser Induced Florescence. ${ }^{d}$ : Chemiluminescence. ${ }^{e}$ : Spectro radiometer. ${ }^{f}$ : Gas and aerosol collector followed by Ion Chromatograph detection. ${ }^{g}$ : Twin Differential Mobility Particle Sizer and Aerodynamic Particle Sizer. ${ }^{\text {h. }}$ Nephelometer and Photoacoustic spectrometer. ${ }^{\text {i }}$ : Meteorology station.

$\mathrm{OH}$ concentrations were measured by laser induced fluorescence (LIF) spectroscopy (Hofzumahaus et al., 2009; Lu et al., 2011). Ambient air was sampled by gas expansion into a low-pressure $(3.5 \mathrm{hPa})$ fluorescence cell, where the $\mathrm{OH}$ radicals were electronically excited by tunable, pulsed UV laser radiation at a wavelength of $308 \mathrm{~nm}$. The resulting $\mathrm{OH}$ resonance fluorescence was detected by time-delayed gated photon counting. The limit of detection was $(0.5-1) \times 10^{6} \mathrm{~cm}^{-3}$ at $5 \mathrm{~min}$ integration time and the accuracy was $20 \%(1 \sigma)$. The laser of the LIF was also used for the $\mathrm{OH}$ reactivity instrument (Lou et al., 2010) which was setup in the same container. This instrument provided $\mathrm{OH}$ reactivities in the range between $1 \mathrm{~s}^{-1}$ and $100 \mathrm{~s}^{-1}$ at 1 min time resolution.

$\mathrm{NO}$ and $\mathrm{NO}_{2}$ were measured by commercial instruments (Takegawa et al., 2006). NO was detected by $\mathrm{NO}-\mathrm{O}_{3}$ chemiluminescence (Thermo Electron, Model 42CTL), while $\mathrm{NO}_{2}$ was first converted to NO in a photolytical reactor (Droplet Measurement Technologies, Model BLC). The 1 min detection limits for $\mathrm{NO}$ and $\mathrm{NO}_{2}$ were $50 \mathrm{ppt}$ and $170 \mathrm{ppt}$, respectively, and the corresponding accuracies were $7 \%$ and $13 \%$. However, during the campaign the instruments were stopped occasionally for repair and maintenance. The gaps (less than $10 \%$ of the data set) were filled with data of a second instrument operated by PKU at the BG site.

The aerosol surface density $S_{\text {a }}$ was calculated from the particle number size distributions between $3 \mathrm{~nm}$ and $10 \mu \mathrm{m}$ by assuming the particles are in spherical shape (Yue et al., 2010). The particle number size distributions were measured by a system consisting of a Twin Differential Mobility Particle Sizer (TDMPS) and an APS (TSI model 3321). The relative humidity within the whole system was kept below $30 \%$ by silica gel tubes within the inlet line and both sheath air cycles. The accuracy of derived $S_{\mathrm{a}}$ was estimated to be around $20 \%$. A hygroscopic factor $f(\mathrm{RH})$ was applied to correct $S_{\mathrm{a}}$ to the aerosol surface density in the real atmosphere $\left(S_{\mathrm{aw}}\right)$.

$$
\begin{aligned}
& f(\mathrm{RH})=1+a \times \mathrm{RH}^{b} \\
& S_{\mathrm{aw}}=S_{\mathrm{a}} \times f(\mathrm{RH})
\end{aligned}
$$

The empirical factors $a$ and $b$ used to estimate $f(\mathrm{RH})$ were set to 2.06 and 3.6, respectively, as described by Liu et al. (2008).

Total aerosol particle scattering coefficients $\left(\sigma_{\mathrm{s}, \lambda}\right)$ and hemispheric backscattering coefficients $\left(\sigma_{\mathrm{bs}, \lambda}\right)$ at three different wavelengths $(\lambda=450 \mathrm{~nm}, 550 \mathrm{~nm}$, and $700 \mathrm{~nm})$ were measured by an integrating nephelometer (Model 3563, TSI). The aerosol particle absorption coefficient at $532 \mathrm{~nm}\left(\sigma_{\mathrm{a}, 532}\right)$ was determined with a photoacoustic spectrometer (PAS; Desert Research Institute), which provides highly sensitive absorption measurements without interference by scattering signals. These two instruments shared the same $\mathrm{PM}_{10}$ inlet with the TDMPS-APS system, and thus provided data at $\approx 30 \%$ relative humidity. The accuracy of the nephelometer and the PAS data was $10 \%$. The aerosol single scattering albedo at $532 \mathrm{~nm}\left(\omega_{532}\right)$ was calculated as the ratio of the interpolated $\sigma_{\mathrm{s}, 532}$ and measured $\sigma_{\mathrm{a}, 532}$ (Garland et al., 2008).

Gaseous nitric acid, $\mathrm{HNO}_{3}$, was measured by a GAC-IC system (Su et al., 2008b). The system consists of a gas and aerosol collector (GAC) and an ion chromatograph detector (IC). The GAC uses an annular wet denuder to collect $\mathrm{HF}$, $\mathrm{HCl}, \mathrm{SO}_{2}, \mathrm{HONO}, \mathrm{HNO}_{3}$ in gas phase and $\mathrm{F}^{-}, \mathrm{Cl}^{-}, \mathrm{SO}_{4}^{2-}$, $\mathrm{NO}_{2}^{-}, \mathrm{NO}_{3}^{-}$in $\mathrm{PM}_{2.5}$. The ambient air was sampled into the denuder through a $6 \mathrm{~m}$ Teflon tube with an air flow rate of $16.71 \mathrm{~min}^{-1}$. The stripping solution used in the denuder was $25 \mu \mathrm{mol} 1^{-1} \mathrm{Na}_{2} \mathrm{CO}_{3}$. The time resolution for all species was 30 min, while the detection limits for $\mathrm{HNO}_{3}$ and aerosol nitrate were $65 \mathrm{ppt}$ and $0.4 \mu \mathrm{g} \mathrm{m}^{-3}$, respectively.

Photolysis frequencies were calculated from solar actinicflux spectra recorded by a spectroradiometer (Meteorologie 
Consult) as described by Bohn et al. (2008). The accuracy of the $\mathrm{HONO}$ photolysis frequency, $J_{\mathrm{HONO}}$, was estimated to be $10 \%$ at solar zenith angles smaller than $80^{\circ}$.

Wind speed and temperature were measured by an ultrasonic anemometer (USA-1, Metek, Germany) on the top of the lab container. A weather station (WXT510, Vaisala, Finland) was located on a small elevation behind the container (20 $\mathrm{m}$ distance). The accuracies for temperature, relative humidity, and pressure were $0.3 \mathrm{~K}, 3 \%$, and $0.5 \mathrm{hPa}$, respectively.

\section{Results}

We performed nearly continuous HONO measurements from 3 to 26 July 2006 (Fig. 2). HONO exhibits a clear diurnal cycle with peaks in the early morning and minima around noontime. The nighttime maxima ranged from $1 \mathrm{ppb}$ to $5 \mathrm{ppb}$. Especially during two days (24 and 25 July) when intense electric cable combustion events happened, the nocturnal HONO concentration exceeded $4 \mathrm{ppb}$ in the early morning hours. During an extended rainfall period (15 to 18 July, influence of typhoon Bilis) the concentration of HONO as well as other trace species were at their lowest level of the campaign. When we average the entire data set the mean maximum HONO concentration was $1.5 \mathrm{ppb}$, occurring around sunrise (Fig. 3b). The average HONO mixing ratio at noon time was about $200 \mathrm{ppt}$, however with large variations between 10 ppt and 490 ppt (Fig. 3b).

The entire campaign was characterized by tropical conditions with high temperatures $\left(28-36^{\circ} \mathrm{C}\right)$ and high humidities between $60 \%$ and $95 \%$ relative humidity (Fig. 2). The rainfall period (Typhoon Bilis) is clearly seen in the relative humidity record with constant values above $90 \%$ throughout the day. It is also represented in the solar radiation which is strongly reduced as shown by the photolysis frequency of $\mathrm{HONO}\left(J_{\mathrm{HONO}}\right)$ and $\mathrm{NO}_{2}\left(J_{\mathrm{NO}_{2}}\right)$. At the field site, local wind speeds were generally slow and had values mostly less than $2 \mathrm{~m} \mathrm{~s}^{-1}$ measured at $8 \mathrm{~m}$ height directly above the HONO inlet. These conditions correspond to the typical summer weather condition in the PRD region. The general weather pattern consists of high temperatures, high humidities, and dense cloud cover as reported by Chan and Yao (2008). The prevailing geostrophic winds are from the southeast, south and southwest due to the monsoon circulation. The typical ground wind speed at inland locations is around $1.5 \mathrm{~m} \mathrm{~s}^{-1}$, a situation which favors the accumulation of air pollutants.

Figure 2 also presents the time series of simultaneously measured trace gases and aerosol parameters. Noontime $\mathrm{OH}$ concentrations reach $(1-2) \times 10^{7} \mathrm{~cm}^{-3}$ on every day when $\mathrm{OH}$ data were reported. However, the LIF instrument could not be operated during the rainfall period due to technical problems. The measured $\mathrm{OH}$ reactivity $\left(k_{\mathrm{OH}}\right)$ record indicates the high level of reactants present. Combining $\mathrm{OH}$ concentrations and reactivities show the enormous turnover

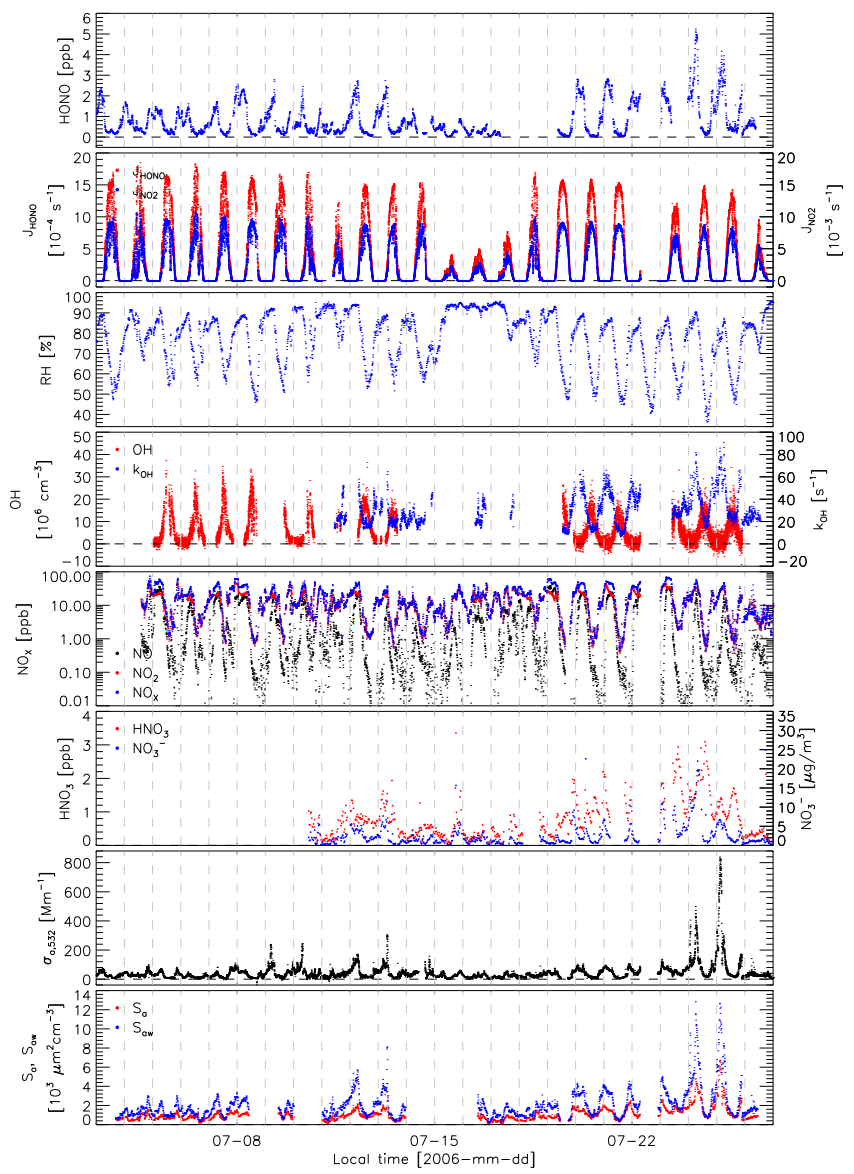

Fig. 2. Time series of $\mathrm{HONO}, J_{\mathrm{HONO}}, J_{\mathrm{NO}_{2}}, \mathrm{RH}, \mathrm{OH}, k_{\mathrm{OH}}, \mathrm{NO}$, $\mathrm{NO}_{2}, \mathrm{NO}_{\mathrm{x}}$, gas phase $\mathrm{HNO}_{3}$, aerosol light absorption $\left(\sigma_{\mathrm{a}}, 532\right)$, aerosol surface density $\left(S_{\mathrm{a}}\right)$ and $\mathrm{RH}$ corrected aerosol surface density $\left(S_{\text {aw }}\right)$ at the Back Garden supersite in July 2006.

under these conditions (Hofzumahaus et al., 2009). At the same time the levels of $\mathrm{NO}$ and $\mathrm{NO}_{2}$ show a large variability. Maximum mixing ratios of $\mathrm{NO}, \mathrm{NO}_{2}$, and $\mathrm{NO}_{\mathrm{x}}$ were $20 \mathrm{ppb}, 30 \mathrm{ppb}$, and $50 \mathrm{ppb}$, occurring in the early morning when all ozone has been titrated by NO emissions. The gas phase $\mathrm{HNO}_{3}$ concentrations are in the range of $100 \mathrm{ppt}$ to $3 \mathrm{ppb}$ with an average of $700 \mathrm{ppt}$, which are comparable with those observed at other rural sites (e.g. Zhou et al., 2007). Similar variations can be found between $\mathrm{HNO}_{3}$ and $\mathrm{HONO}$.

In contrast to the gas phase parameters shown here, the aerosols exhibit a less pronounced diurnal variation, as demonstrated by the aerosol surface density $\left(S_{\mathrm{a}}\right.$ and $\left.S_{\mathrm{aw}}\right)$ and aerosol light absorption $\left(\sigma_{\mathrm{a}, 532}\right)$ in Fig. 2 . The major variation comes from the different pollution levels, namely the burning events at the end of the campaign. The elevated values strongly reduced the visibility to values in the order of 1-2 km. The aerosol surface density and aerosol light absorption show a very similar pattern. Therefore, the aerosol light absorption can fill gaps in the aerosol surface density record, i.e. in the rainfall period. 
Table 2. Overview on HONO measurements performed in or in the vicinity of big cities. The daytime values correspond to $\pm 3 \mathrm{~h}$ around local noon, the nighttime values reperesent averages between sunset and sunrise.

\begin{tabular}{|c|c|c|c|c|c|c|c|c|c|c|c|c|}
\hline \multirow[t]{2}{*}{ Location } & \multirow[t]{2}{*}{ Date } & \multicolumn{2}{|c|}{ HONO [ppb] } & \multicolumn{2}{|c|}{$\mathrm{NO}_{2}[\mathrm{ppb}]$} & \multicolumn{2}{|c|}{$\mathrm{NO}_{\mathrm{x}}[\mathrm{ppb}]$} & \multicolumn{2}{|c|}{$\mathrm{HONO} / \mathrm{NO}_{2}$} & \multicolumn{2}{|c|}{$\mathrm{HONO} / \mathrm{NO}_{\mathrm{x}}$} & \multirow[t]{2}{*}{ Ref. } \\
\hline & & night & day & night & day & night & day & night & day & night & day & \\
\hline Santiago (Chile) & Mar 2005 & 3.00 & 1.50 & 30.0 & 20.0 & 200.0 & 40.0 & 0.100 & 0.075 & 0.015 & 0.038 & 1 \\
\hline Guangzhou (China) & Jun 2006 & 3.50 & 2.00 & 20.0 & 30.0 & n.a. ${ }^{d}$ & n.a. & 0.175 & 0.067 & n.a. & n.a. & 2 \\
\hline Seoul (Korea) & May-Jul 2005 & 0.36 & 0.36 & 56.0 & 56.0 & n.a. & n.a. & 0.006 & 0.006 & n.a. & n.a. & 3 \\
\hline Kathmandu (Nepal) & n-Feb 2003 & 1.74 & 0.35 & 17.9 & 8.6 & 20.1 & 13.0 & 0.097 & 0.041 & 0.087 & 0.027 & 4 \\
\hline Taichung (Taiwar & 1-Jan 2005/2006 & 1.50 & 0.50 & 25.0 & 16.7 & n.a. & n.a. & 0.060 & 0.030 & n.a. & n.a. & 5 \\
\hline Xinken (China) & Oct-Nov 2004 & 1.30 & 0.80 & 34.8 & 30.0 & 37.8 & 40.0 & 0.037 & 0.027 & 0.034 & 0.020 & 6 \\
\hline Rome (Italy) & May-Jun 2001 & 1.00 & 0.15 & 27.2 & 4.0 & 51.2 & 4.2 & 0.037 & 0.038 & 0.020 & 0.036 & 7 \\
\hline Milan (Italy) & 1998 & 0.92 & 0.14 & 33.2 & 18.3 & 117.5 & 23.4 & 0.028 & 0.008 & 0.008 & 0.006 & 8 \\
\hline Shanghai (China) & Oct-Jan 2004/2005 & 1.50 & 0.35 & 26.0 & 16.0 & n.a. & n.a. & 0.058 & 0.022 & n.a. & n.a. & 9 \\
\hline Tokyo (Japan) & Jan-Feb 2004 & 0.80 & 0.05 & 31.8 & 18.2 & 37.4 & 26.3 & 0.025 & 0.003 & 0.021 & 0.002 & 10 \\
\hline Mexico City (Mexico) & Mar 2006 & n.a. & 0.43 & n.a. & 28.4 & n.a. & 44.8 & n.a. & 0.015 & n.a. & 0.010 & 11 \\
\hline Pabstthum $^{\mathrm{a}}$ (Germany) & Jul-Aug 1998 & 0.33 & 0.07 & 2.9 & 3.6 & 3.3 & 4.6 & 0.112 & 0.018 & 0.099 & 0.014 & 12 \\
\hline Yufa $^{\mathrm{b}}$ (China) & Jul-Aug 2006 & 0.89 & 0.43 & 14.2 & 8.0 & 18.3 & 9.4 & 0.062 & 0.054 & 0.048 & 0.046 & 13 \\
\hline Houston (USA) & Sep 2006 & 0.5 & 0.1 & 20.0 & 10.0 & n.a. & n.a. & 0.025 & 0.010 & n.a. & n.a. & 14 \\
\hline Backgarden $^{\mathrm{c}}$ (China) & Jun 2006 & 0.95 & 0.24 & 16.5 & 4.5 & 20.9 & 5.5 & 0.057 & 0.053 & 0.045 & 0.043 & - \\
\hline
\end{tabular}

${ }^{a}$ : near Berlin. ${ }^{\text {b }}$ : near Beijing. ${ }^{\text {c }}$ : near Guangzhou. ${ }^{\text {d }}$ : not available. 1: Elshorbany et al. (2009); 2: Qin et al. (2009); 3: Song et al. (2009); 4: Yu et al. (2009); 5: Cheng et al. (2008); 6: Su et al. (2008a,b); 7: Acker et al. (2006a); 8: Alicke et al. (2002); 9: Hao et al. (2006); 10: Kanaya et al. (2007); 11: Dusanter et al. (2009); 12: Alicke et al. (2003); 13: Yang et al. (2010); 14: Wong et al. (2011).

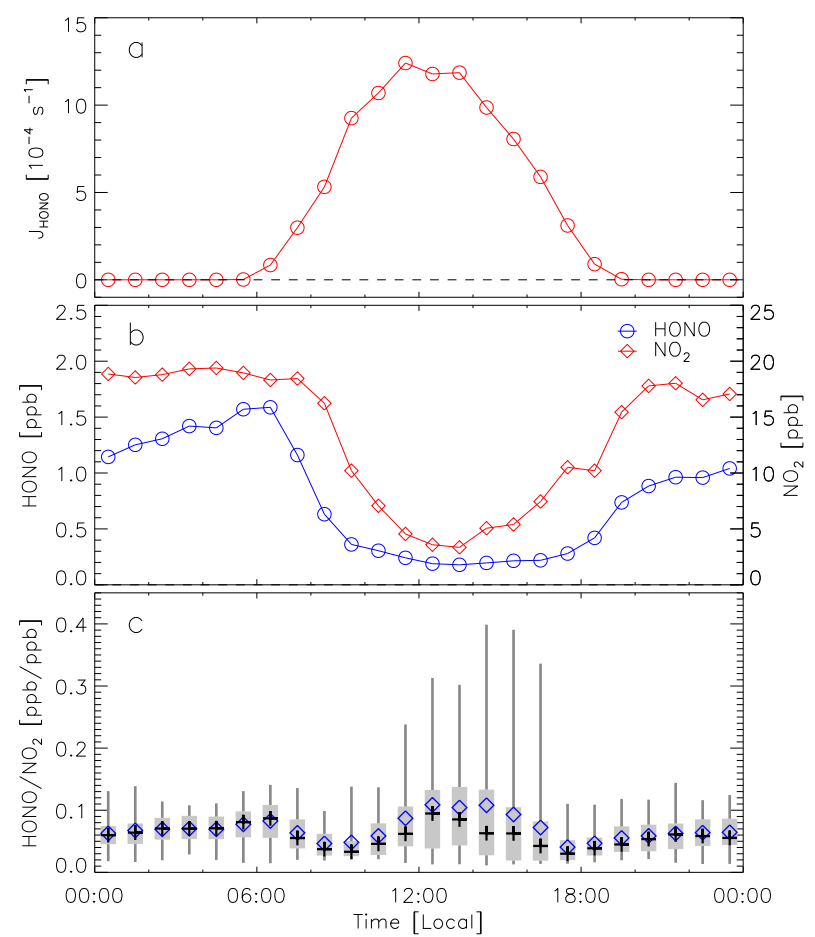

Fig. 3. Mean diurnal cycle of $J_{\mathrm{HONO}}, \mathrm{HONO}, \mathrm{NO}_{2}$ and $\mathrm{HONO} / \mathrm{NO}_{2}$ at the Back Garden supersite in July 2006. In (c), the + refers to the median, boxes represent $50 \%$ (25\% to $75 \%$ ), the whiskers $90 \%$ of the data. The blue diamond is the average.

\section{Discussion}

\subsection{HONO concentrations and the influence of direct HONO emissions}

The observed HONO concentrations with maximum values above $5 \mathrm{ppb}$ at night and of $200 \mathrm{ppt}$ at overhead sun (Fig. 2) are among the highest ever recorded at a site outside of big cities (cf. Alicke et al., 2003; Kleffmann et al., 2005; Cheng et al., 2007; Shon et al., 2007; Zhou et al., 2007). However, when we refer to campaign averages and relate them to measurements which were done in or in the vicinity of big cities (Table 2) we see that the BG data are at the low end for nighttime and almost average for daytime observations. Our nighttime values compare to Beijing and Tokyo values, while daytime mixing ratios are lower than other observations in Asia. In order to relate the HONO concentration to the level of local pollution and the possible HONO sources, the $\mathrm{HONO}$ to $\mathrm{NO}_{2}$ and/or the $\mathrm{HONO}$ to $\mathrm{NO}_{\mathrm{x}}$ ratio has been used in many publications to create a more stable value for charactering the level of HONO.

The ratio $\mathrm{HONO} / \mathrm{NO}_{2}$ has the advantage of being less influenced by convection or transport processes than individual concentrations and it can be used to indicate the heterogeneous conversion efficiency of $\mathrm{NO}_{2}$ to $\mathrm{HONO}$. However, when a large fraction of HONO comes from direct emissions the ratio might be influenced. Emission ratios of HONO to $\mathrm{NO}_{2}$ were measured to be less than $1 \%$ as reported by Kurtenbach et al. (2001, and references therein). 
Considering the conversion from $\mathrm{NO}_{2}$ to $\mathrm{HONO}$, higher value of $\mathrm{HONO} / \mathrm{NO}_{2}$ can be expected for an aged air mass. The $\mathrm{HONO} / \mathrm{NO}_{2}$ observed in many field studies range from $2 \%$ to $10 \%$ with lower values in the fresh air masses (Febo et al., 1996; Lammel and Cape, 1996; Alicke et al., 2002, 2003; Stutz et al., 2004; Zhou et al., 2007; Su et al., 2008b; Sörgel et al., 2011b). The measured $\mathrm{HONO} / \mathrm{NO}_{2}$ during the PRIDE-PRD2006 campaign ranged from $<1.1 \%$ (1\% quantile) to $>35 \%$ (99\% quantile) with mean value of $7.1 \pm 6.1 \%$. The recorded $\mathrm{HONO} / \mathrm{NO}_{2}$ greater than $35 \%$ exceed the ever reported highest ratio by Yu et al. (2009) (i.e. 30\% during 00:00-03:00 LT at Kathmandu). However, different from Yu et al. (2009), the high ratios obtained by us always occurred during 12:00-15:00 LT.

Figure $3 \mathrm{c}$ displays the mean diurnal variation of $\mathrm{HONO} / \mathrm{NO}_{2}$ at the $\mathrm{BG}$ site. In general, the highest ratios with large variability were found from 11:00 to 17:00 LT, even higher than those during the nights. This can be attributed to the efficient daytime formation of HONO which is not correlated to $\mathrm{NO}_{2}$ (see Fig. 9 and the discussion about the additional $\mathrm{HONO}$ source below). On average, $\mathrm{HONO} / \mathrm{NO}_{2}$ started to increase shortly after sunset and kept stable at $\approx 6 \%$ in the rest of the night. The increase of $\mathrm{HONO} / \mathrm{NO}_{2}$ was accompanied by the simultaneous increase of $\mathrm{HONO}$ and $\mathrm{NO}_{2}$, suggesting the heterogeneous conversion from $\mathrm{NO}_{2}$ to HONO. Once the conversion reached a steady state, the $\mathrm{HONO} / \mathrm{NO}_{2}$ became stable. The covariation between $\mathrm{HONO}$ and $\mathrm{NO}_{2}$ during nighttime (19:00-06:00 LT) can further be seen from the correlation plot (Fig. 4b), indicating $\mathrm{NO}_{2}$ as the precursor of HONO in this time interval. Figure $4 \mathrm{~b}$ also shows the dependence of the $\mathrm{HONO} / \mathrm{NO}_{2}$ ratio on the aerosol surface density $\left(S_{\text {aw }}\right)$ during night. Higher values of $\mathrm{HONO} / \mathrm{NO}_{2}$ are usually found at higher levels of $S_{\text {aw }}$, suggesting the possible influence of aerosol surfaces on the heterogeneous $\mathrm{NO}_{2}$ to HONO conversion. However, as will be discussed later, compared to the ground surfaces, the influence of aerosol surfaces on the HONO formation is small. The nighttime stable $\mathrm{HONO} / \mathrm{NO}_{2}$ values were slightly higher than that observed by $\mathrm{Su}$ et al. (2008a) $(4.3 \pm 1.5 \%)$ in the same region. The decrease of $\mathrm{HONO} / \mathrm{NO}_{2}$ can be caused by emissions or transport. The increase of $\mathrm{HONO} / \mathrm{NO}_{2}$ and its high value during daytime suggests a high $\mathrm{HONO}$ formation efficiency, which however might not be solely explained by the $\mathrm{NO}_{2}$ conversion given the weak correlation between $\mathrm{HONO}$ and $\mathrm{NO}_{2}$ (Fig. 4a). Moreover, as higher $\mathrm{HONO} / \mathrm{NO}_{2}$ ratios are usually found at lower RH level (Fig. 4a), the daytime HONO formation is unlikely caused by Reaction (R5). As will be discussed later, additional HONO production mechanisms are needed to sustain the high daytime level of $\mathrm{HONO}$ as well as $\mathrm{HONO} / \mathrm{NO}_{2}$.

As the BG site was characterized by occasional local emissions from biomass and electric cable burning processes, it is necessary to separate HONO formed by chemical reactions from directly emitted. Emission factors of HONO are only available for vehicles obtained through either tun-
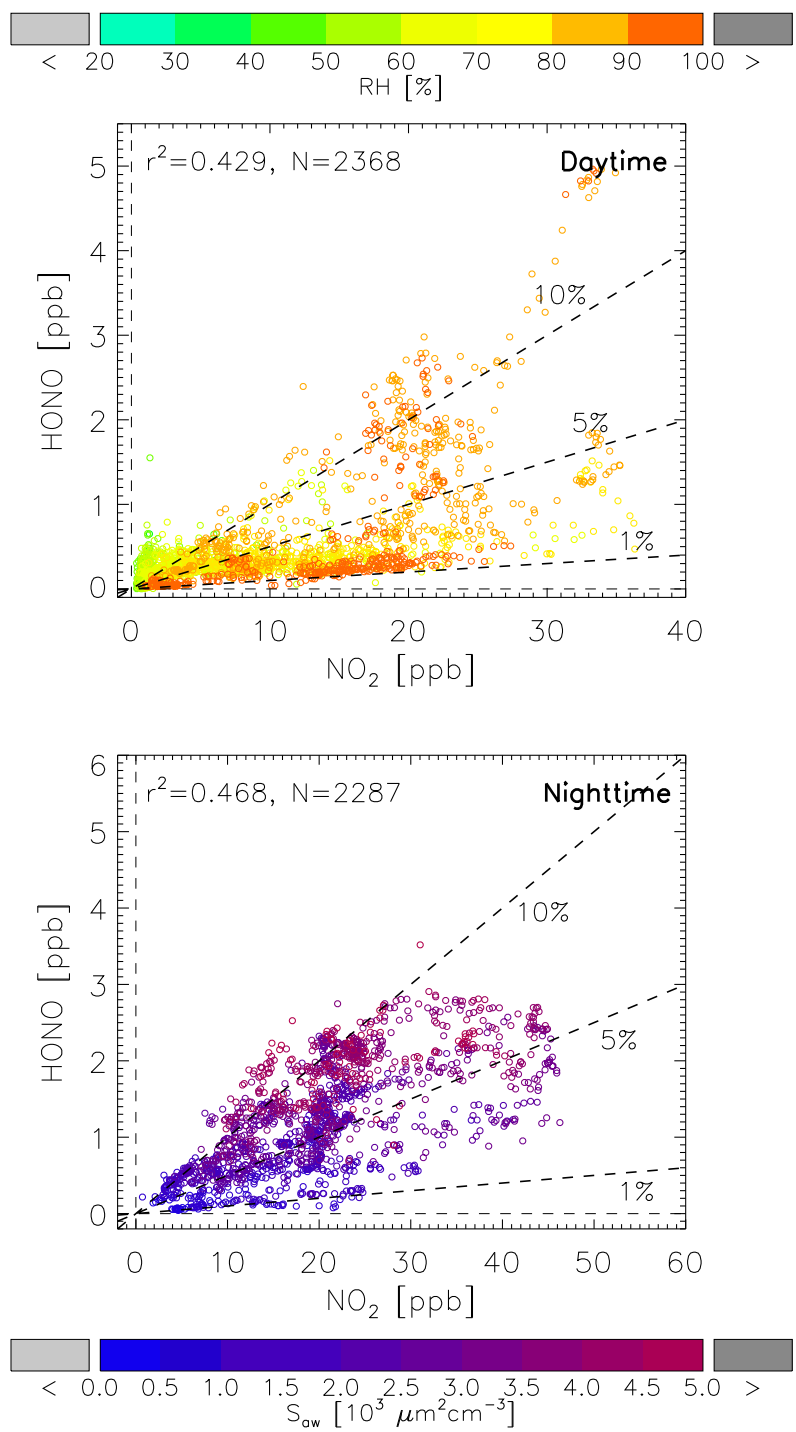

Fig. 4. Correlation between $\mathrm{HONO}$ and $\mathrm{NO}_{2}$. The dashed lines correspond to the $\mathrm{HONO} / \mathrm{NO}_{2}$ ratio of $10 \%, 5 \%$ and $1 \%$. The nighttime data are in the time period of 19:00-06:00 LT and color coded by the aerosol surface density; while the daytime data are color coded by the relative humidity.

nel experiments or laboratory studies in the US and Europe (Kurtenbach et al., 2001, and references therein). Considering the differences in combustion processes, fuel compositions, etc., the reported emission of $\mathrm{HONO}$ relative to $\mathrm{NO}_{\mathrm{x}}$ (i.e. $\mathrm{HONO} / \mathrm{NO}_{\mathrm{x}}$ ) might not be representative for PRD region. In order to evaluate the influence of direct emissions, we tried to estimate the local HONO emission factor from the ambient measurements.

When the air mass is getting aged, due to the conversion from $\mathrm{NO}_{2}$ to $\mathrm{HONO}$, the $\mathrm{HONO} / \mathrm{NO}_{\mathrm{x}}$ ratio will increase; the freshly emitted air mass should have the lowest $\mathrm{HONO} / \mathrm{NO}_{\mathrm{x}}$. Thus, we used the observed lowest $\mathrm{HONO} / \mathrm{NO}_{\mathrm{x}}$ as the upper limit for the emission factor. Besides, two other filters as 


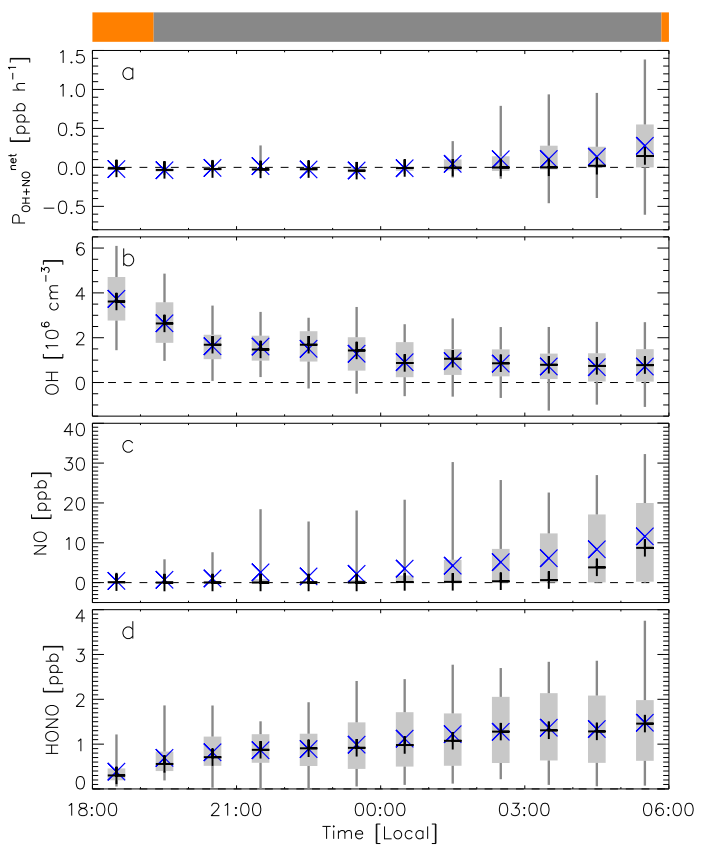

Fig. 5. Mean nocturnal variation of $P_{\mathrm{OH}+\mathrm{NO}}^{\text {net }}, \mathrm{OH}$, $\mathrm{NO}$ and $\mathrm{HONO}$. The color bar illustrates the local day (orange) and night (grey). These box-whisker diagram are based on $1 \mathrm{~h}$ averages for time intervals where both measurements were present. The + refers to the median, boxes represent $50 \%$ (25\% to $75 \%$ ), the whiskers $90 \%$ of the data. The blue $\times$ is the average.

proposed by Su et al. (2008a) were applied: (1) only nighttime data were included in order to avoid the fast photolysis of $\mathrm{HONO}$; (2) $\mathrm{NO} \geq 20 \mathrm{ppb}$ was used to catch the fresh emissions. The derived $\mathrm{HONO} / \mathrm{NO}_{\mathrm{x}}$ is $1.8 \%$ much higher than $0.8 \%$ reported by Kurtenbach et al. (2001). During the experiments conducted by Kurtenbach et al. (2001), air masses were characterized by $\mathrm{NO} / \mathrm{NO}_{\mathrm{x}} \geq 95 \%$. The typical $\mathrm{NO} / \mathrm{NO}_{\mathrm{x}}$ ratio in our measurements is $\approx 50 \%$, suggesting the air detected is a mixture of freshly emitted and aged. Therefore, a substantial part of HONO is secondary. Since the observed $\mathrm{NO} / \mathrm{NO}_{\mathrm{x}}$ and $\mathrm{HONO} / \mathrm{NO}_{\mathrm{x}}$ during the entire campaign period has an average of $13 \%$ and $6 \%$, respectively, the influence of direct emissions on HONO should be small and hence be ignored in the following analysis.

\subsection{HONO during night}

The nocturnal pattern observed here is similar to ever reported: HONO increases after sunset to a maximum at sunrise. Since most of the dynamic range of the HONO concentration is during the night, the correlation between HONO and $\mathrm{NO}_{2}$ is mostly created during nighttime hours. In this section, we will focus on the formation pathways of the nocturnal HONO and explore the relevant factors.

\subsubsection{Gas phase formation through $\mathrm{OH}+\mathrm{NO}$}

During the PRIDE-PRD2006 campaign, a substantial measured $\mathrm{OH}$ concentration of $\approx 1 \times 10^{6} \mathrm{~cm}^{-3}$ together with NO mixing ratios larger than $2 \mathrm{ppb}$ were found in the night (Fig. 5b, c), which brings up the importance of $\mathrm{OH}+\mathrm{NO}$ on the nighttime HONO formation. Taking Reactions (R2) and (R9) into account, the net HONO production is

$P_{\mathrm{OH}+\mathrm{NO}}^{\text {net }}=k_{\mathrm{OH}+\mathrm{NO}}[\mathrm{OH}][\mathrm{NO}]-k_{\mathrm{OH}+\mathrm{HONO}}[\mathrm{OH}][\mathrm{HONO}]$

The mean nocturnal variation of $P_{\mathrm{OH}+\mathrm{NO}}^{\text {net }}$ is illustrated in Fig. 5a. Since $k_{\mathrm{OH}+\mathrm{NO}}$ and $k_{\mathrm{OH}+\mathrm{HONO}}$ are similar (7.2 and 5.0 in units of $10^{-12} \mathrm{~cm}^{3} \mathrm{~s}^{-1}$ at $298 \mathrm{~K}$ ), the $P_{\mathrm{OH}+\mathrm{NO}}^{\text {net }}$ depends on the relative abundance of $\mathrm{NO}$ and HONO. Before midnight, due to the low NO level, small negative value of $P_{\mathrm{OH}+\mathrm{NO}}^{\text {net }}$ was found. The formation of $\mathrm{HONO}$ in this time period might mostly come from the $\mathrm{NO}_{2}$ conversion as will be discussed later. After midnight, with the sharp increase of $\mathrm{NO}$ mixing ratios, the $P_{\mathrm{OH}+\mathrm{NO}}^{\text {net }}$ increased from 0 to $0.28 \mathrm{ppbh}^{-1}$. Higher $P_{\mathrm{OH}+\mathrm{NO}}^{\text {net }}$ of $0.4-0.9 \mathrm{ppb} \mathrm{h}^{-1}$ were found by Wong et al. (2011) for the nocturnal urban atmosphere of Houston. By integrating $P_{\mathrm{OH}+\mathrm{NO}}^{\text {net }}$ from 00:00 to $06: 00 \mathrm{LT}$, an accumulated HONO formation of $0.66 \mathrm{ppb}$ can be derived. However, the averaged measured HONO accumulation in this time period was only $0.36 \mathrm{ppb}$. This suggested that, (1) the reaction of $\mathrm{OH}+\mathrm{NO}$ is enough to explain the increase of $\mathrm{HONO}$ in the second half of the night, even though sources like $\mathrm{NO}_{2}$ conversion might still existed; (2) the strength of HONO sinks other than $\mathrm{OH}+$ HONO should be at least in the order of $0.05 \mathrm{ppbh}^{-1}$ (i.e. $(0.66 \mathrm{ppb}-0.36 \mathrm{ppb}) / 6 \mathrm{~h})$.

\subsubsection{Heterogeneous conversion of $\mathrm{NO}_{2}$}

Figure 6 illustrates the correlation between HONO, $\mathrm{HONO} / \mathrm{NO}_{2}$, RH corrected aerosol surface density from $3 \mathrm{~nm}$ to $10 \mu \mathrm{m}\left(S_{\text {aw }}\right)$ and aerosol light absorption at $532 \mathrm{~nm}$ $\left(\sigma_{\mathrm{a}, 532}\right)$. As the $\mathrm{HONO}$ production by $\mathrm{OH}+\mathrm{NO}$ was prominent in the second half of the night, we restrict the correlation analysis to the time frame 18:00-0:00 LT. Both HONO and $\mathrm{HONO} / \mathrm{NO}_{2}$ increase with $S_{\mathrm{a}}$ and $\sigma_{\mathrm{a}, 532}$. Compared with $\mathrm{HONO} / \mathrm{NO}_{2}, \mathrm{HONO}$ has better correlation with $S_{\mathrm{aw}}$ and $\sigma_{\mathrm{a}, 532}$, which was probably due to the decrease of boundary layer height leading to the simultaneous concentration change of trace gases and aerosols. Whilst this effect can largely be canceled out in the $\mathrm{HONO} / \mathrm{NO}_{2}$. The positive correlation between $\mathrm{HONO} / \mathrm{NO}_{2}$ and $S_{\text {aw }}$ indicates the $\mathrm{HONO}$ formation on aerosol surfaces through the heterogeneous conversion of $\mathrm{NO}_{2}$, which has already been found in Fig. $4 \mathrm{~b}$. However, considering the correlation is weak $\left(r^{2}=0.184\right)$, the relative amount of HONO formed on aerosol surfaces might be small. The $\sigma_{\mathrm{a}, 532}$ provides the information of black carbon or soot content in the atmosphere. The even weaker correlation between $\mathrm{HONO} / \mathrm{NO}_{2}$ and $\sigma_{\mathrm{a}, 532}$ indicates a small 

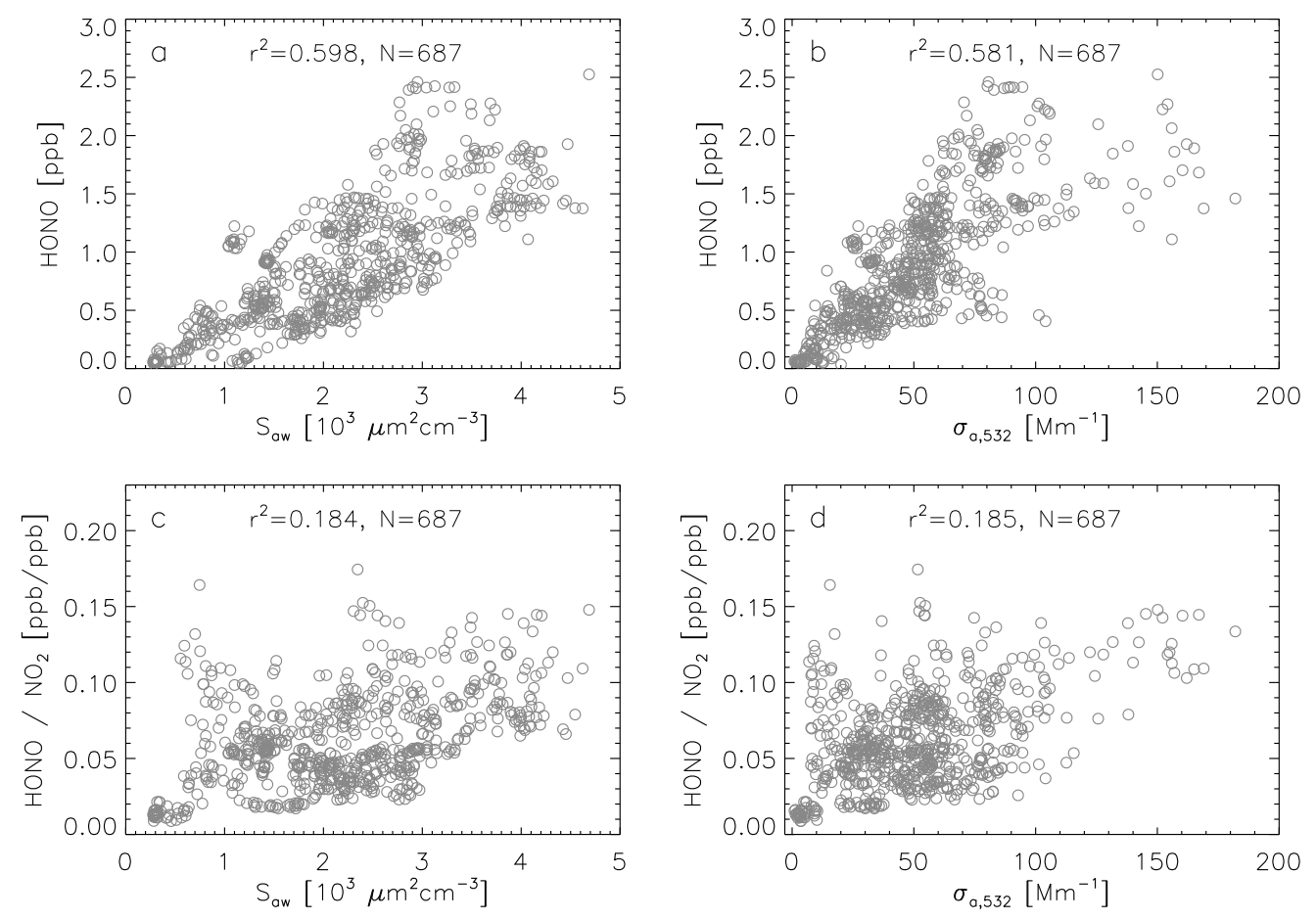

Fig. 6. Correlations between $\mathrm{HONO} / \mathrm{NO}_{2}, \mathrm{HONO}$, aerosol surface density (RH corrected), aerosol light absorption during the time interval of 18:00-00:00 LT.

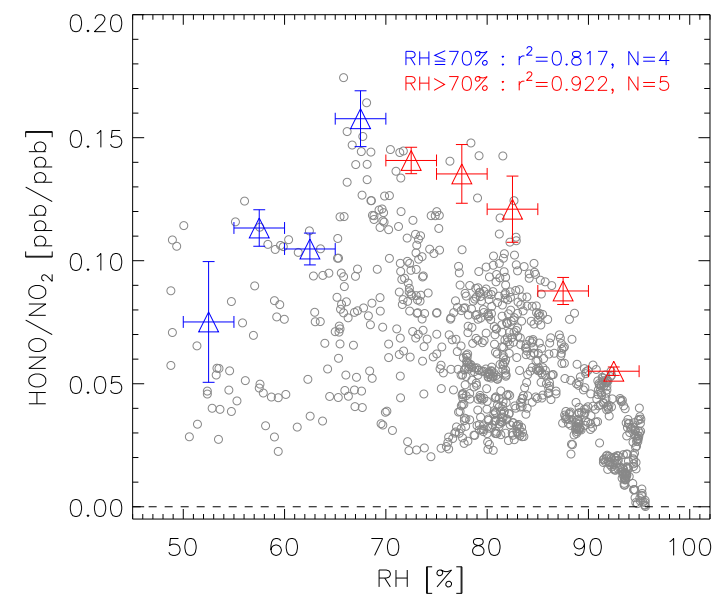

Fig. 7. Scatter plot of $\mathrm{HONO} / \mathrm{NO}_{2}$ against $\mathrm{RH}$ in the time interval of 18:00-00:00 LT (time interval avoids influence of $\mathrm{OH}+\mathrm{NO}$, see Fig. 5). Triangles are the averaged top-5 $\mathrm{HONO} / \mathrm{NO}_{2}$ in each $5 \%$ RH interval.

role of soot in the heterogeneous HONO formation. The relationship between $\mathrm{HONO} / \mathrm{NO}_{2}$ and relative humidity $\mathrm{RH}$ is illustrated in Fig. 7. Following the method introduced by Stutz et al. (2004), we analyzed the top-5 $\mathrm{HONO} / \mathrm{NO}_{2}$ values in each $5 \%$ RH interval. These are less influenced by factors like the time of the night, the surface density, advection, etc. The dependence of $\mathrm{HONO} / \mathrm{NO}_{2}$ on $\mathrm{RH}$ can be divided into two groups. An increase of $\mathrm{HONO} / \mathrm{NO}_{2}$ along with RH was found when RH was less than $70 \%$, which is consistent with the kinetics of Reaction (R5). Once RH was higher than $70 \%$, the $\mathrm{NO}_{2}$ to $\mathrm{HONO}$ conversion efficiency depended negatively on RH. The same phenomenon was also observed by Yu et al. (2009) in Kathmandu. This finding can be associated with the number of water layers formed on various surfaces increases rapidly with relative humidity, leading to an efficient uptake of HONO. Thus HONO is lost in the gas phase when on the surface loss becomes dominant (Lammel, 1999; Stutz et al., 2004).

Using the data from the first half of the night (18:0000:00 LT), we calculated the HONO conversion frequency $C_{\mathrm{HONO}}$ by Eq. (2). The average value of $C_{\mathrm{HONO}}$ during the campaign was $0.024 \pm 0.015 \mathrm{~h}^{-1}$, corresponding to a HONO production rate by $\mathrm{NO}_{2}\left(P_{\mathrm{NO}_{2}}\right)$ of $0.38 \pm 0.25 \mathrm{ppbh}^{-1}$ (i.e. $\left.C_{\mathrm{HONO}} \times \overline{\left[\mathrm{NO}_{2}\right]}\right)$. It is necessary to note that, (1) the $C_{\mathrm{HONO}}$ assumes all the measured HONO is coming from the conversion of $\mathrm{NO}_{2}$; and (2) the derived $P_{\mathrm{NO}_{2}}$ is the net $\mathrm{HONO}$ production, which means sinks of HONO (e.g. deposition, $\mathrm{HONO}+\mathrm{OH}$, etc.) have already been taken into account in $P_{\mathrm{NO}_{2}}$. The HONO conversion frequency obtained in this work is comparable to observations of Su et al. (2008b) in the same region $\left(0.016 \pm 0.014 \mathrm{~h}^{-1}\right)$ and by Alicke et al. (2003) at a rural site in Pabstthum $\left(0.018 \pm 0.009 \mathrm{~h}^{-1}\right)$, but much higher than observation at other places (e.g. Lammel, 1999; Alicke et al., 2002; Acker et al., 2005; Sörgel et al., 2011a,b). 
The formation of $\mathrm{HONO}$ through heterogeneous $\mathrm{NO}_{2}$ conversion on aerosol surfaces $\left(S_{\mathrm{aw}}\right)$ depends on many factors and can be approximated by

$P_{\text {hetero }}=\frac{1}{4} \gamma_{\mathrm{NO}_{2} \rightarrow \mathrm{HONO}} \times S_{\mathrm{aw}} \times v_{\mathrm{NO}_{2}} \times\left[\mathrm{NO}_{2}\right]$

where $\gamma \mathrm{NO}_{2} \rightarrow \mathrm{HONO}$ is the uptake coefficient of $\mathrm{NO}_{2}$ to $\mathrm{HONO}$, and $\nu_{\mathrm{NO}_{2}}$ the mean molecular velocity of $\mathrm{NO}_{2}$ (Ammann et al., 1998). If the entire HONO formation were taking place on aerosol surfaces of with density $S_{\text {aw }}$, $\gamma \mathrm{NO}_{2} \rightarrow$ HONO calculated from Eqs. (2) and (10) would have an average of $(2.8 \pm 1.5) \times 10^{-5}$. Using the measured single scattering albedo at $532 \mathrm{~nm} \omega_{532}$, and considering the soot particles are usually hydrophobic, the soot surface density can be roughly estimated as $S_{\text {soot }}=\left(1-\omega_{532}\right) \times S_{\mathrm{a}}$. Further assuming all HONO was formed on soot surfaces, the average value of $\gamma_{\mathrm{NO}_{2} \rightarrow \mathrm{HONO}}^{\text {sot }}$ was found to be $(3.0 \pm 1.8) \times 10^{-4}$. As discussed by Kleffmann et al. (1998), this value seems too high for ambient aerosols. Especially for soot particles, along with the air mass is getting aged, the $\gamma_{\mathrm{NO}_{2} \rightarrow \mathrm{HONO}}^{\mathrm{soot}}$ will decrease dramatically to a value which is in the order of $10^{-5}$ (Aubin and Abbatt, 2007). Moreover, given the weak correlation of $\mathrm{NO}_{2}$ to $\mathrm{HONO}$ conversion efficiency against $S_{\text {aw }}$ and $\sigma_{\mathrm{a}, 532}$, we conclude that the HONO production was mostly taking place at ground surfaces rather than aerosols during nighttime. These ground surfaces could include the surfaces of plants, buildings, soils and so on in surrounding areas which can typically provide orders of magnitude higher surface density than aerosols (Sörgel et al., 2011b). A similar conclusion was drawn from recent studies in both forest and urban areas (Sörgel et al., 2011b; Wong et al., 2011).

\subsubsection{Removal of HONO through deposition}

In Sect. 4.2.1, we mentioned that the production of HONO estimated from gas phase reactions (i.e. Reactions (R2) and (R9)) was larger than that from the measurement. Moreover, as the heterogeneous $\mathrm{NO}_{2}$ conversion can also take place in the second half of the night, this discrepancy will become even larger. Assuming a constant $C_{\mathrm{HONO}}$ over night and the extra HONO are all removed through deposition on the ground, the HONO deposition velocity $v_{\mathrm{HONO}}^{\text {ground }}$ can be roughly estimated by,

$\frac{d[\mathrm{HONO}]}{d t}=P_{\mathrm{OH}+\mathrm{NO}}^{\mathrm{net}}+C_{\mathrm{HONO}} \times \overline{\left[\mathrm{NO}_{2}\right]}-\frac{\nu_{\mathrm{HONO}}^{\text {ground }} \times[\mathrm{HONO}]}{H}$

The $v_{\text {HONO }}^{\text {ground }}$ calculated from the mean nocturnal variation (00:00-06:00 LT in Fig. 5) is $\approx 0.8 \mathrm{~cm} \mathrm{~s}^{-1}$ taken the night time $H$ of $100 \mathrm{~m}$. This value is substantially higher than observations by Stutz et al. (2002) $\left(0.077 \mathrm{~cm} \mathrm{~s}^{-1}\right)$ but within the range of other published results $\left(0.5-3 \mathrm{~cm} \mathrm{~s}^{-1}\right)$ (Harrison and Kitto, 1994; Harrison et al., 1996; Spindler et al., 1999). The estimated high value of $v_{\text {HONO }}^{\text {ground }}$ seems to be in line with the high RH during night which increases the water adsorbed at ground surfaces and favor the adsorption of HONO.

\subsubsection{Formation of HONO on ground surfaces}

As illustrated above, the nighttime HONO production was mainly from the heterogeneous $\mathrm{NO}_{2}$ conversion on ground surfaces, which can be described as,

$C_{\mathrm{HONO}}=\frac{P_{\mathrm{HONO}}}{\overline{\left[\mathrm{NO}_{2}\right]}}=\frac{\phi_{\mathrm{NO}_{2} \rightarrow \mathrm{HONO}} \times \nu_{\mathrm{NO}_{2}}^{\text {ground }}}{H}-\frac{\nu_{\mathrm{HONO}}^{\text {ground }}}{H} \times \frac{[\mathrm{HONO}]}{\overline{\left[\mathrm{NO}_{2}\right]}}$

where $v_{\mathrm{NO}_{2}}^{\text {ground }}$ and $\phi_{\mathrm{NO}_{2} \rightarrow \mathrm{HONO}}$ is the dry deposition velocity of $\mathrm{NO}_{2}$ and the yield of $\mathrm{HONO}$ from deposited $\mathrm{NO}_{2}$, respectively (Su et al., 2008a). By definition, $\phi_{\mathrm{NO}_{2} \rightarrow \mathrm{HONO}}$ varies between 0 and 1 , accounting for the fact that the deposited $\mathrm{NO}_{2}$ molecule is not necessarily converted to HONO. As the controlling resistances were the aerodynamic resistance and the quasi-laminar layer resistance during night, similar deposition velocities were expected for $\mathrm{NO}_{2}$ and HONO. Thus, using the measured average value of $C_{\mathrm{HONO}}, \mathrm{NO}_{2}, \mathrm{HONO}$ and the estimated $\nu_{\mathrm{HONO}}^{\text {ground }}$, and assuming a $100 \mathrm{~m}$ height of the well-mixed layer, a $\phi_{\mathrm{NO}_{2} \rightarrow \mathrm{HONO}}$ value of 0.15 was found which means that one out of seven deposited $\mathrm{NO}_{2}$ forms HONO being released into the atmosphere. Our derived $\phi_{\mathrm{NO}_{2} \rightarrow \mathrm{HONO}}$ is lower than that by Su et al. (2008a) (0.34), which is mainly caused by using the different value of $\nu_{\mathrm{NO}_{2}}^{\text {ground }}$ during the calculation.

\subsection{Daytime HONO budget}

The HONO data presented here were accompanied by simultaneous measurements of $\mathrm{OH}, \mathrm{NO}$, and $J_{\mathrm{HONO}}$. Therefore, we can examine the HONO budget and HONO lifetime directly from measured quantities. The HONO chemical lifetime $\left(\tau_{\mathrm{HONO}}\right)$ due to photolysis (Reaction R1) and reaction with $\mathrm{OH}$ (Reaction $\mathrm{R} 9$ ) was $\approx 50 \mathrm{~min}$ after sunrise and before sunset and decreased to $\approx 13$ min under overhead sun conditions. Due to the short lifetime, especially around noon, HONO is in quasi steady state and we can calculate the budget of HONO from gas phase production and loss in the same way as Kleffmann et al. (2005) and Acker et al. (2006b) did for two rural sites in Germany. In order to justify the quasi steady state assumptions associated with Eqs. (4) and (5), we restricted the data set to $J_{\mathrm{HONO}}>8 \times 10^{-4} \mathrm{~s}^{-1}$. Under these conditions, the HONO lifetime was less than $20 \mathrm{~min}$, and $d[\mathrm{HONO}] / d t$ calculated from the measurements was small and evenly distributed around zero.

The $P_{M}$ and $\mathrm{HONO}_{\mathrm{M}}$ (see Eqs. 4, 5, and 6) for the "high $J$ subset" are shown in Fig. 8 (blue dots). The value of $P_{M}$ was significantly higher than zero in most of the time, which corresponds to a substantial amount of $\mathrm{HONO}_{\mathrm{M}}$. Also shown in Fig. 8 are the mean diurnal variations of $P_{M}, \mathrm{HONO}_{\mathrm{M}}$ and measured HONO (open circles). The average $P_{M}$ during the entire campaign period was $0.77 \pm 0.55 \mathrm{ppb} \mathrm{h}^{-1}$, which is comparable to observations by Kleffmann et al. (2005) in the forest in Jülich $\left(\approx 0.55 \mathrm{ppb} \mathrm{h}^{-1}\right)$ and by Wong et al. (2012) in downtown Houston $\left(\approx 0.6 \mathrm{ppb} \mathrm{h}^{-1}\right)$, but smaller than the estimation by Su et al. (2008b) in XinKen $\left(\approx 2 \mathrm{ppb} \mathrm{h}^{-1}\right)$. Since 


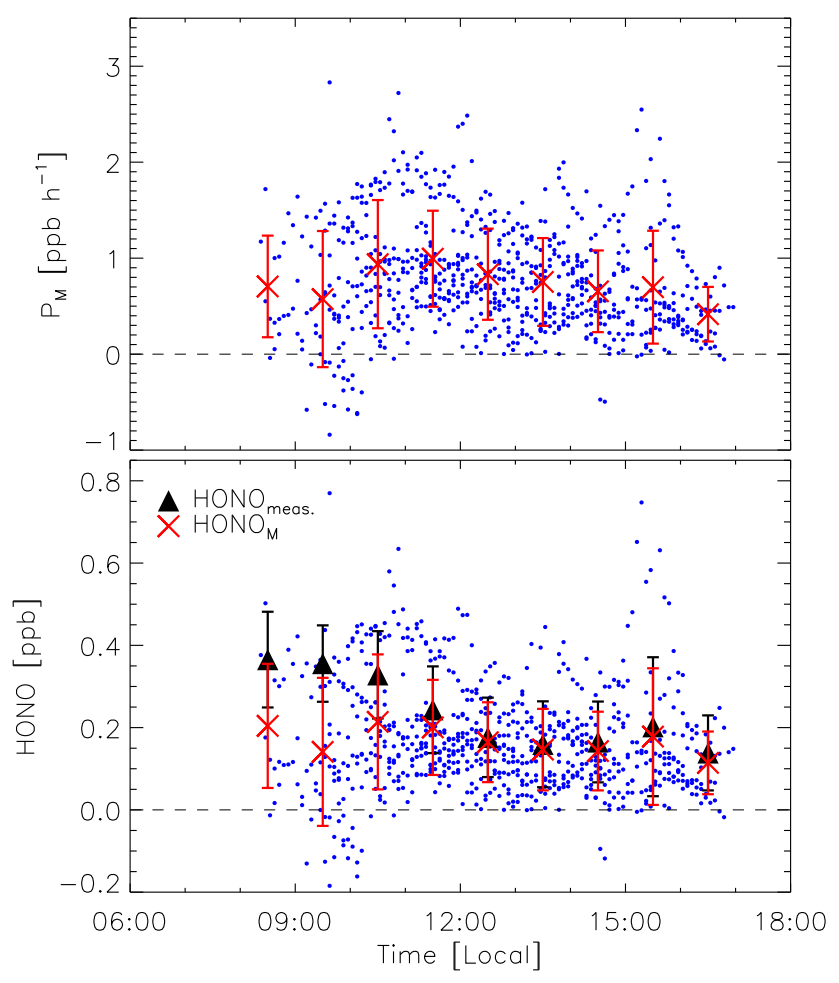

Fig. 8. Upper frame: Calculated additional HONO production rate $P_{M}$ (Eq. 4). The blue dots correspond all 5-min averages where measurements of $J_{\mathrm{HONO}}, \mathrm{OH}, \mathrm{NO}$ and $\mathrm{HONO}$ were present. The red circles refer to the mean over $1 \mathrm{~h}$ with $1-\sigma$ error bars. Lower: additional HONO concentration $\mathrm{HONO}_{\mathrm{M}}$ (Eq. 5). Red circles are the mean values over $1 \mathrm{~h}$, black triangles are the mean value of the measured HONO.

the daytime average minima of HONO in XinKen was as high as $1.2 \mathrm{ppb}$, higher value of $P_{M}$ can be expected. $P_{M}$ in the order of $0.1-2 \mathrm{ppbh}^{-1}$ are also found in other rural and urban areas (Elshorbany et al., 2009; Ren et al., 2010; Sörgel et al., 2011a). The $\mathrm{HONO}_{\mathrm{M}}$ was the dominant part of measured HONO, accounting for $>95 \%$ since 11:00 LT. This means the daytime HONO formation was controlled by $P_{M}$ while only a minor part $(<5 \%)$ came from gas phase $\mathrm{OH}+\mathrm{NO}$ reaction.

Similar temporal variation pattern can be found between $P_{M}$ and $\mathrm{HONO} / \mathrm{NO}_{2}$ (Fig. 3c). The simultaneous increase of $P_{M}$ and $\mathrm{HONO} / \mathrm{NO}_{2}$ after 09:00 LT indicates either the elevated conversion efficiency from $\mathrm{NO}_{2}$ to $\mathrm{HONO}$ or the existence of unknown HONO sources during daytime. Recent studies showed the heterogeneous $\mathrm{NO}_{2}$ reaction forming HONO on various surfaces being photosensitive or photoenhanced (George et al., 2005; Stemmler et al., 2006). Therefore, higher HONO production rate can be expected when surfaces are exposed to sunlight. The production of HONO through the proposed mechanisms should be related to parameters including the gas phase $\mathrm{NO}_{2}$ concentration, $\mathrm{RH}$, aerosol/ground surface area density, soot/organic composition on the surfaces, etc. The correlations of $P_{M}$ against $\mathrm{NO}_{2}, \mathrm{RH}, J_{\mathrm{NO}_{2}}, S_{\text {aw }}$ and $\sigma_{\mathrm{a}, 532}$ do not provide a clear picture (Fig. 9). Relationship is neither found neither between $P_{M}$ and $J_{\mathrm{NO}_{2}}$ nor between $P_{M}$ and RH. According to Stemmler et al. (2006), the photosensitized HONO production will become saturated when the irradiance is above $200 \mathrm{~W} \mathrm{~m}^{-2}$. Since our data are restricted to high $J_{\mathrm{HONO}}$ we did not explore the sensitive region in the laboratory study. A similar phenomenon was observed by Stemmler et al. (2007) with regard to RH, thus the range of humidities explored here might not be sensitive again. The correlation between $P_{M}$ and $\mathrm{NO}_{2}$ is two-fold. For $\mathrm{NO}_{2}$ less than $4.5 \mathrm{ppb}$, a weak increase can be observed (Fig. 9a), while at higher $\mathrm{NO}_{2}$ the values decrease (Fig. 9b). The higher $\mathrm{NO}_{2}$ were only observed during the early morning (08:00-10:00 LT) and might caused by the $\mathrm{NO}$ to $\mathrm{NO}_{2}$ conversion, the lower light levels and the lower boundary height.

The weak dependence of $P_{M}$ on $S_{\mathrm{aw}}$ and $\sigma_{\mathrm{a}, 532}$ suggests the aerosol surfaces might not be the places where $\mathrm{HONO}_{\mathrm{M}}$ is formed. Even weaker relationship between $P_{M}$ and parameters in Fig. 9 was found for individual measurement days except 24 July. The prevailing cable combustion events in surrounding areas happened during the night of 23 to 24 July. The high aerosol surface density and the soot concentration caused by the strong primary emissions could facilitate the HONO formation on aerosols. However, since the dependence of $P_{M}$ on parameters in Fig. 9 is generally weak, we thought the contribution of heterogeneous $\mathrm{NO}_{2}$ reaction to $P_{M}$ should be quite small. To further prove our assumption, we calculated the $\gamma_{\mathrm{NO}_{2} \rightarrow \mathrm{HONO},} \gamma_{\mathrm{NO}_{2} \rightarrow \mathrm{HONO}}^{\text {soot }}$, and $\phi_{\mathrm{NO}_{2} \rightarrow \mathrm{HONO}}$ around noon (11:00-13:00 LT) by assuming $P_{M}$ is only taking place on aerosol, soot particle and ground surfaces, respectively. The mean value of $\gamma \mathrm{NO}_{2} \rightarrow \mathrm{HONO}$ and $\gamma_{\mathrm{NO}_{2} \rightarrow \mathrm{HONO}}^{\mathrm{soot}}$ derived from Eq. (10) is 0.03 and 0.39 , respectively. These values are three to four orders of magnitude higher than those obtained in laboratory studies. Using a mixing height of $250 \mathrm{~m}$ as suggested by Stemmler et al. (2006) and assuming the same dry deposition velocity between day and night, the mean value of $\phi_{\mathrm{NO}_{2} \rightarrow \mathrm{HONO}}$ calculated by Eq. (12) is 135. This value is far away from the theoretical range (i.e. 0 to 1 ) and could not be explained by the uncertainty of $v_{\mathrm{HONO}}^{\text {ground }}\left(v_{\mathrm{NO}_{2}}^{\text {ground }}\right)$. Therefore, we concluded that the contribution of heterogenous $\mathrm{NO}_{2}$ reaction to $P_{M}$ was quite small. Other HONO formation mechanisms are needed during daytime.

The photolysis of adsorbed $\mathrm{HNO}_{3}$ on ground surfaces was suggested to be the major HONO source at Whiteface Mountain in the US (Zhou et al., 2003, 2007). As the adsorption of $\mathrm{HNO}_{3}$ on ground surfaces occurs day and night, and the amount of adsorbed $\mathrm{HNO}_{3}$ is proportional to the gas phase $\mathrm{HNO}_{3}$ concentration, we correlated the average noontime $P_{M}$ with the GAC-IC measured $\mathrm{HNO}_{3}$ concentrations averaged over the previous $24 \mathrm{~h}$ period (Fig. 10a). A possitive correlation was found for the limited days when continuous 

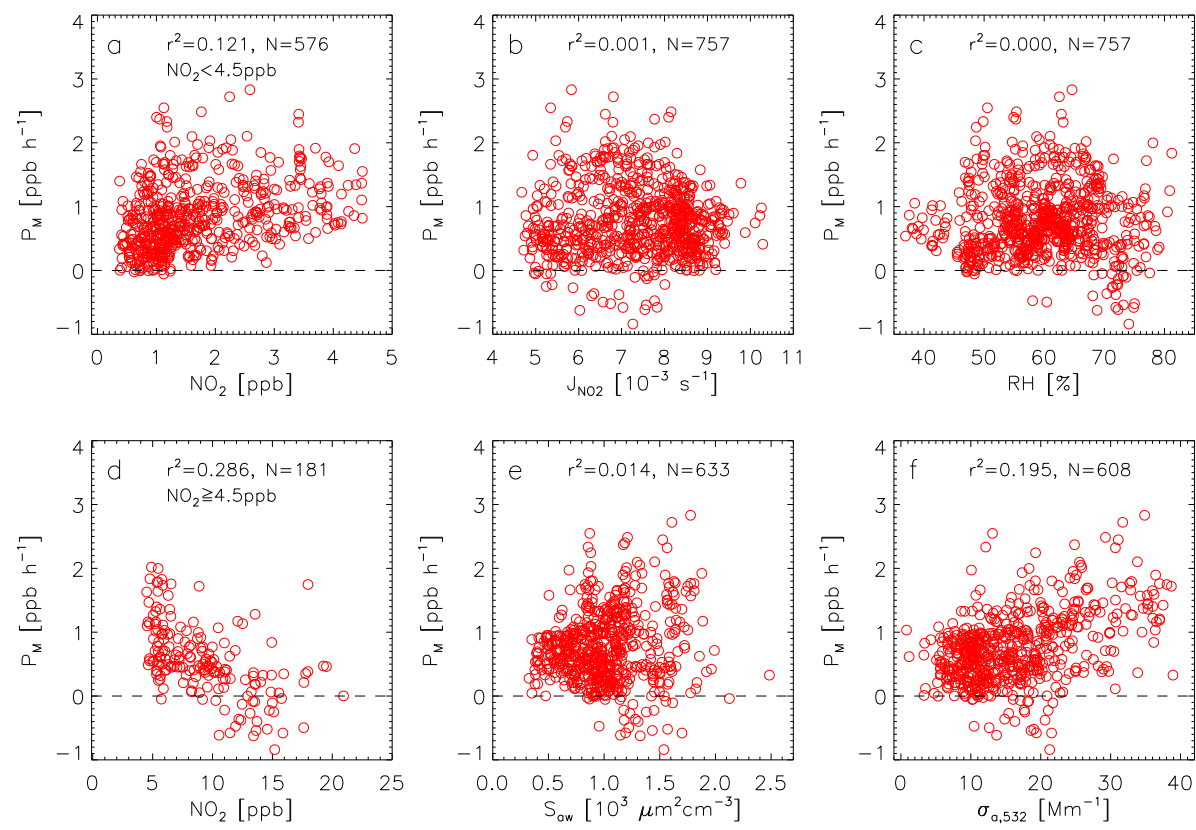

Fig. 9. Correlation of $P_{M}$ against $\mathrm{NO}_{2}, J_{\mathrm{NO}_{2}}, \mathrm{RH}, S_{\mathrm{aw}}$, and $\sigma_{\mathrm{a}, 532}$.
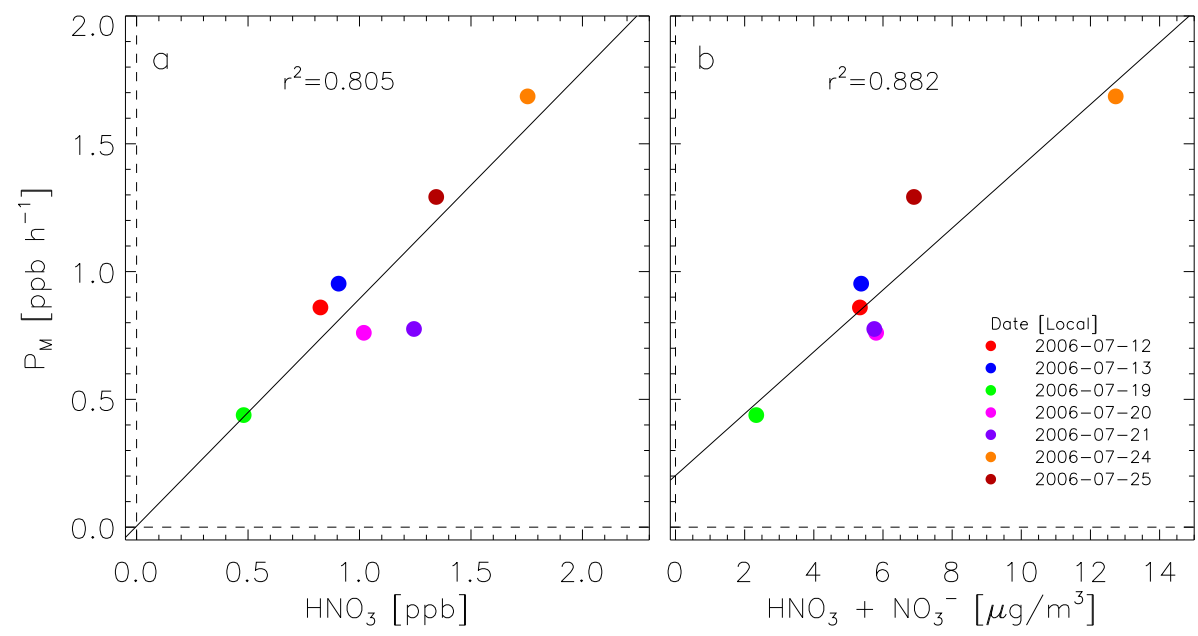

Fig. 10. Correlation of the average noontime (11:00-13:00 LT) additional HONO production rate $\left(P_{M}\right)$ against the averaged $\mathrm{HNO}_{3}$ concentration over the previous $24 \mathrm{~h}$ period (a) and the sum of the averaged $\mathrm{HNO}_{3}$ and aerosol nitrate (b). The seven data points are color-coded for the different days of the campaign. The slopes of the regression lines represent a parameterization of the HONO formation rate, see text for details.

$\mathrm{HNO}_{3}$ measurements were available $\left(r^{2}=0.81\right)$. The firstorder approximation of production rate of HONO through this mechanism can be calculated as (Zhou et al., 2007),

$P_{\mathrm{HNO}_{3} \rightarrow \mathrm{HONO}}=\frac{f \times\left[\mathrm{HNO}_{3}\right] \times \nu_{\mathrm{HNO}_{3}} \times t_{\mathrm{d}} \times j_{\mathrm{HNO}_{3} \rightarrow \mathrm{HONO}}}{H}$

where $f$ is the fraction of noontime full sun to which the surfaces were exposed, $v_{\mathrm{HNO}_{3}}$ is the dry deposition velocity of $\mathrm{HNO}_{3}$ over $t_{\mathrm{d}}$ period, and $j_{\mathrm{HNO}_{3} \rightarrow \mathrm{HONO}}$ the photolysis rate constant of $\mathrm{HNO}_{3}$ via HONO pathway. Here, by assuming the surfaces containing $\mathrm{HNO}_{3}$ within a mix- ing height of $250 \mathrm{~m}$ were exposed to $f=1 / 4$ noontime full sun, taking $\nu_{\mathrm{HNO}_{3}}=5 \mathrm{~cm} \mathrm{~s}^{-1}$ over $t_{\mathrm{d}}=24 \mathrm{~h}$, and using the average value of $P_{M}=0.97 \mathrm{ppbh}^{-1}$ and $\left[\mathrm{HNO}_{3}\right]=1.1 \mathrm{ppb}$ in Fig. 10a, the photolysis frequency $j_{\mathrm{HNO}_{3} \rightarrow \mathrm{HONO}}$ derived from Eq. (13) was $5.7 \times 10^{-5} \mathrm{~s}^{-1}$. This value is comparable to measurments by Zhou et al. (2003) in the laboratory $\left((1.2 \pm 0.2) \times 10^{-5} \mathrm{~s}^{-1}\right)$. In addition, we also correlated the noontime $P_{M}$ with the sum of the $\mathrm{HNO}_{3}$ concentrations averaged over the previous $24 \mathrm{~h}$ period and the aerosol nitrate, both measured by GAC-IC (Fig. 10b). This scatter plot has 
an even higher correlation $\left(r^{2}=0.88\right)$ and the photolysis frequency $j_{\mathrm{HNO}_{3} \rightarrow \mathrm{HONO}}$ of $2.5 \times 10^{-5} \mathrm{~s}^{-1}$ is clsoer to the value obtained by Zhou et al. (2003). Given the good correlation of $P_{M}$ with $\mathrm{HNO}_{3}$ and the sum of $\mathrm{HNO}_{3}$ and aerosol nitrate, we concluded that the photolysis of adsorbed $\mathrm{HNO}_{3}$ on ground surfaces in surrounding areas could be one likely source for the missing daytime additional HONO formation. This is also supported the value of the calculated $j_{\mathrm{HNO}_{3} \rightarrow \mathrm{HONO}}$.

Recently, Su et al. (2011) demonstrated that the soil nitrite, which is formed through the biological nitrification and denitrification processes, can be the source of HONO. The soil HONO emission $\left(P_{\text {soil }}\right)$ was estimated to be $2-5 \mathrm{ppb} \mathrm{h}^{-1}$ for Xinken site. Since the BG site is surrounded by farmland, we can not exclude the possibility that the soil nitrite contributes to $P_{M}$. However, even if Xinken and BG are located in the same region, they represent different environments: Xinken is located at the southeast end of PRD around $200 \mathrm{~km}$ south of the Backgarden site. Xinken is at the seaside (at the Zhujiang river estuary) and located in a land reclamation area. However, the magnitude of the estimated $P_{\text {soil }}$ covers our observed $P_{M}$. Since we did not measure the relevant information with regard to the nitrite concentration, the temperature, the $\mathrm{pH}$ value and the water content of the soil in the surrounding area during the campaign, it is difficult to quantify the $P_{\text {soil }}$ and thus its contribution to $P_{M}$.

\section{Conclusions}

We performed continuous measurements of atmospheric nitrous acid (HONO) at Back Garden supersite (BG) in Pearl River Delta (PRD) in China, for 4 weeks in July 2006. The observed HONO concentrations are among the highest ever reported for rural areas, consistent with the fact that the PRD is one of the "hot-spots" of the $\mathrm{HONO}$ precursor $\mathrm{NO}_{2}$ in the world.

Different from former studies in the same region (Su et al., 2008a,b; Qin et al., 2009), we for the first time have a full set of online measurements which are relevant for exploring the HONO formation. It is found that the direct emissions from combustion processes only have minor influence on the observed HONO concentration. During night, the reaction of $\mathrm{OH}+\mathrm{NO}$ and the heterogeneous conversion of $\mathrm{NO}_{2}$ on ground surfaces are the major sources of HONO. The observed net $\mathrm{HONO}$ production from $\mathrm{OH}+\mathrm{NO}$ reaction can be up to $0.28 \mathrm{ppbh}^{-1}$. The average conversion frequency of $\mathrm{NO}_{2}$ to HONO was found to be $0.024 \mathrm{~h}^{-1}$ which is higher than other places in the world. During daytime, to sustain the HONO concentration at $\approx 200 \mathrm{ppt}$, an additional HONO production $\left(P_{M}\right)$ rate of $0.77 \mathrm{ppbh}^{-1}$ is needed in addition to the productions from the well-known gas phase reactions. Our analysis demonstrated that, $P_{M}$ did not relate to the heterogeneous $\mathrm{NO}_{2}$ conversion, but relate to the photolysis of adsorbed $\mathrm{HNO}_{3}$ on ground surfaces. There is the possibility that an unknown portion of $P_{M}$ is correlated with the soil nitrite. However, the validation of this assumption requires on-site measurements of the soil chemical and physical properties.

Acknowledgements. This work was supported by the China National Basic Research and Development Program 2002CB410801, and the National High Technology Research and Development Program of China (863 Program) 2006AA06A301.

Edited by: S. C. Liu

\section{References}

Acker, K., Möller, D., Auel, R., Wieprecht, W., and Kalass, D.: Concentrations of nitrous acid, nitric acid, nitrite and nitrate in the gas and aerosol phase at a site in the emission zone during ESCOMPTE 2001 experiment, Atmos. Res., 74, 507-524, doi:10.1016/j.atmosres.2004.04.009, 2005.

Acker, K., Febo, A., Trick, S., Perrino, C., Bruno, P., Wiesen, P., Möller, D., Wieprecht, W., Auel, R., Giusto, M., Geyer, A., Platt, U., and Allegrini, I.: Nitrous acid in the urban area of Rome, Atmos. Environ., 40, 3123-3133, doi:10.1016/j.atmosenv.2006.01.028, 2006a.

Acker, K., Möller, D., Wieprecht, W., Meixner, F. X., Bohn, B., Gilge, S., Plass-Dülmer, C., and Berresheim, H.: Strong daytime production of $\mathrm{OH}$ from $\mathrm{HNO}_{2}$ at a rural mountain site, Geophys. Res. Lett., 33, L02809, doi:10.1029/2005g1024643, 2006 b.

Akimoto, H., Takagi, H., and Sakamaki, F.: Photoenhancement of the nitrous acid formation in the surface reaction of nitrogen dioxide and water vapor: Extra radical source in smog chamber experiments, Int. J. Chem. Kinet., 19, 539-551, doi:10.1002/kin.550190606, 1987.

Alicke, B., Platt, U., and Stutz, J.: Impact of nitrous acid photolysis on the total hydroxyl radical budget during the Limitation of Oxidant Production/Pianura Padana Produzione di Ozono study in Milan, J. Geophys. Res., 107, 8196, doi:10.1029/2000jd000075, 2002.

Alicke, B., Geyer, A., Hofzumahaus, A., Holland, F., Konrad, S., Pätz, H. W., Schäfer, J., Stutz, J., Volz-Thomas, A., and Platt, U.: $\mathrm{OH}$ formation by HONO photolysis during the BERLIOZ experiment, J. Geophys. Res., 108, 8247, doi:10.1029/2001jd000579, 2003.

Amedro, D., Parker, A. E., Schoemaecker, C., and Fittschen, C.: Direct observation of $\mathrm{OH}$ radicals after $565 \mathrm{~nm}$ multi-photon excitation of $\mathrm{NO}_{2}$ in the presence of $\mathrm{H}_{2} \mathrm{O}$, Chem. Phys. Lett., 513, 12-16, doi:10.1016/j.cplett.2011.07.062, 2011.

Ammann, M., Kalberer, M., Jost, D. T., Tobler, L., Rossler, E., Piguet, D., Gaggeler, H. W., and Baltensperger, U.: Heterogeneous production of nitrous acid on soot in polluted air masses, Nature, 395, 157-160, doi:10.1038/25965, 1998.

Ammann, M., Rossler, E., Strekowski, R., and George, C.: Nitrogen dioxide multiphase chemistry: uptake kinetics on aqueous solutions containing phenolic compounds, Phys. Chem. Chem. Phys., 7, 2513-2518, doi:10.1039/b501808k, 2005.

Aubin, D. G. and Abbatt, J. P. D.: Interaction of $\mathrm{NO}_{2}$ with hydrocarbon soot: focus on HONO yield, surface modification, and mechanism, J. Phys. Chem. A, 111, 6263-6273, doi:10.1021/jp068884h, 2007. 
Beine, H. J., Amoroso, A., Dominé, F., King, M. D., Nardino, M., Ianniello, A., and France, J. L.: Surprisingly small HONO emissions from snow surfaces at Browning Pass, Antarctica, Atmos. Chem. Phys., 6, 2569-2580, doi:10.5194/acp-6-2569-2006, 2006.

Bejan, I., Abd El Aal, Y., Barnes, I., Benter, T., Bohn, B., Wiesen, P., and Kleffmann, J.: The photolysis of ortho-nitrophenols: a new gas phase source of HONO, Phys. Chem. Chem. Phys., 8, 20282035, doi:10.1039/B516590C, 2006.

Bohn, B., Corlett, G. K., Gillmann, M., Sanghavi, S., Stange, G., Tensing, E., Vrekoussis, M., Bloss, W. J., Clapp, L. J., Kortner, M., Dorn, H.-P., Monks, P. S., Platt, U., PlassDülmer, C., Mihalopoulos, N., Heard, D. E., Clemitshaw, K. C., Meixner, F. X., Prevot, A. S. H., and Schmitt, R.: Photolysis frequency measurement techniques: results of a comparison within the ACCENT project, Atmos. Chem. Phys., 8, 53735391, doi:10.5194/acp-8-5373-2008, 2008.

Bröske, R., Kleffmann, J., and Wiesen, P.: Heterogeneous conversion of $\mathrm{NO}_{2}$ on secondary organic aerosol surfaces: A possible source of nitrous acid (HONO) in the atmosphere?, Atmos. Chem. Phys., 3, 469-474, doi:10.5194/acp-3-469-2003, 2003.

Carr, S., Heard, D. E., and Blitz, M. A.: Comment on "Atmospheric hydroxyl radical production from electronically excited $\mathrm{NO}_{2}$ and $\mathrm{H}_{2} \mathrm{O}$ ”, Science, 324, 336-336, doi:10.1126/science.1166669, 2009.

Chan, C. K. and Yao, X.: Air pollution in mega cities in China, Atmos. Environ., 42, 1-42, doi:10.1016/j.atmosenv.2007.09.003, 2008.

Cheng, M.-T., Horng, C.-L., and Lin, Y.-C.: Characteristics of atmospheric aerosol and acidic gases from urban and forest sites in Central Taiwan, B. Environ. Contam. Tox., 79, 674-677, doi:10.1007/s00128-007-9296-2, 2007.

Cheng, M.-T., Chen, S.-P., Lin, Y.-C., Jung, C.-C., and Horng, C.L.: Concentrations and formation rates of ambient nitrous acid in Taichung City, Taiwan, Environ. Eng. Sci., 25, 1149-1158, doi:10.1089/ees.2007.0124, 2008.

Dusanter, S., Vimal, D., Stevens, P. S., Volkamer, R., and Molina, L. T.: Measurements of $\mathrm{OH}$ and $\mathrm{HO}_{2}$ concentrations during the MCMA-2006 field campaign - Part 1: Deployment of the Indiana University laser-induced fluorescence instrument, Atmos. Chem. Phys., 9, 1665-1685, doi:10.5194/acp-9-16652009, 2009.

Elshorbany, Y. F., Kurtenbach, R., Wiesen, P., Lissi, E., Rubio, M., Villena, G., Gramsch, E., Rickard, A. R., Pilling, M. J., and Kleffmann, J.: Oxidation capacity of the city air of Santiago, Chile, Atmos. Chem. Phys., 9, 2257-2273, doi:10.5194/acp-92257-2009, 2009.

Febo, A., Perrino, C., and Allegrini, I.: Measurement of nitrous acid in milan, italy, by doas and diffusion denuders, Atmos. Environ., 30, 3599-3609, doi:10.1016/1352-2310(96)00069-6, 1996.

Finlayson-Pitts, B. J. and Pitts, J. N.: Chemistry of the Upper and Lower Atmosphere - Theory, Experiments and Applications, 1st edn., Academic Press, San Diego, USA, 2000.

Finlayson-Pitts, B. J., Wingen, L. M., Sumner, A. L., Syomin, D., and Ramazan, K. A.: The heterogeneous hydrolysis of $\mathrm{NO}_{2}$ in laboratory systems and in outdoor and indoor atmospheres: an integrated mechanism, Phys. Chem. Chem. Phys., 5, 223-242, doi:10.1039/B208564J, 2003.

Garland, R. M., Yang, H., Schmid, O., Rose, D., Nowak, A.,
Achtert, P., Wiedensohler, A., Takegawa, N., Kita, K., Miyazaki, Y., Kondo, Y., Hu, M., Shao, M., Zeng, L. M., Zhang, Y. H., Andreae, M. O., and Pöschl, U.: Aerosol optical properties in a rural environment near the mega-city Guangzhou, China: implications for regional air pollution, radiative forcing and remote sensing, Atmos. Chem. Phys., 8, 5161-5186, doi:10.5194/acp-8-5161-2008, 2008.

George, C., Strekowski, R. S., Kleffmann, J., Stemmler, K., and Ammann, M.: Photoenhanced uptake of gaseous $\mathrm{NO}_{2}$ on solid organic compounds: a photochemical source of HONO?, Faraday Discuss., 130, 195-210, doi:10.1039/B417888M, 2005.

Hao, N., Zhou, B., Chen, D., and Chen, L.: Observations of nitrous acid and its relative humidity dependence in Shanghai, J. Environ. Sci., 18, 910-915, doi:10.1016/S1001-0742(06)60013-2, 2006.

Harrison, R. M. and Kitto, A.-M. N.: Evidence for a surface source of atmospheric nitrous acid, Atmos. Environ., 28, 1089-1094, doi:10.1016/1352-2310(94)90286-0, 1994.

Harrison, R. M., Peak, J. D., and Collins, G. M.: Tropospheric cycle of nitrous acid, J. Geophys. Res., 101, 14429-14439, doi:10.1029/96jd00341, 1996.

Heland, J., Kleffmann, J., Kurtenbach, R., and Wiesen, P.: A new instrument to measure gaseous nitrous acid (HONO) in the atmosphere, Environ. Sci. Technol., 35, 3207-3212, doi:10.1021/es000303t, 2001.

Hofzumahaus, A., Rohrer, F., Lu, K., Bohn, B., Brauers, T., Chang, C.-C., Fuchs, H., Holland, F., Kita, K., Kondo, Y., Li, X., Lou, S., Shao, M., Zeng, L., Wahner, A., and Zhang, Y.: Amplified trace gas removal in the Troposphere, Science, 324, 17021704, doi:10.1126/science.1164566, 2009.

Kanaya, Y., Cao, R., Akimoto, H., Fukuda, M., Komazaki, Y., Yokouchi, Y., Koike, M., Tanimoto, H., Takegawa, N., and Kondo, Y.: Urban photochemistry in central Tokyo: 1. Observed and modeled $\mathrm{OH}$ and $\mathrm{HO}_{2}$ radical concentrations during the winter and summer of 2004, J. Geophys. Res., 112, D21312, doi:10.1029/2007jd008670, 2007.

Kleffmann, J., Becker, K. H., and Wiesen, P.: Heterogeneous $\mathrm{NO}_{2}$ conversion processes on acid surfaces: possible atmospheric implications, Atmos. Environ., 32, 2721-2729, doi:10.1016/s13522310(98)00065-x, 1998.

Kleffmann, J., Becker, K. H., Lackhoff, M., and Wiesen, P.: Heterogeneous conversion of $\mathrm{NO}_{2}$ on carbonaceous surfaces, Phys. Chem. Chem. Phys., 1, 5443-5450, doi:10.1039/A905545B, 1999.

Kleffmann, J., Gavriloaiei, T., Hofzumahaus, A., Holland, F., Koppmann, R., Rupp, L., Schlosser, E., Siese, M., and Wahner, A.: Daytime formation of nitrous acid: a major source of $\mathrm{OH}$ radicals in a forest, Geophys. Res. Lett., 32, L05818, doi:10.1029/2005g1022524, 2005.

Kleffmann, J., Lörzer, J. C., Wiesen, P., Kern, C., Trick, S., Volkamer, R., Rodenas, M., and Wirtz, K.: Intercomparison of the DOAS and LOPAP techniques for the detection of nitrous acid (HONO), Atmos. Environ., 40, 3640-3652, doi:10.1016/j.atmosenv.2006.03.027, 2006.

Kurtenbach, R., Becker, K. H., Gomes, J. A. G., Kleffmann, J., Lörzer, J. C., Spittler, M., Wiesen, P., Ackermann, R., Geyer, A., and Platt, U.: Investigations of emissions and heterogeneous formation of HONO in a road traffic tunnel, Atmos. Environ., 35, 3385-3394, doi:10.1016/s1352-2310(01)00138-8, 2001. 
Lammel, G.: Formation of Nitrous acid: Parameterisation and comparison with observatins, Technical report, Max-Planck Institute for Meteorology, Hamburg, Germany, 1999.

Lammel, G. and Cape, J. N.: Nitrous acid and nitrite in the atmosphere, Chem. Soc. Rev., 25, 361-369, doi:10.1039/CS9962500361, 1996.

Li, S., Matthews, J., and Sinha, A.: Atmospheric hydroxyl radical production from electronically excited $\mathrm{NO}_{2}$ and $\mathrm{H}_{2} \mathrm{O}$, Science, 319, 1657-1660, doi:10.1126/science.1151443, 2008.

Li, X., Brauers, T., Shao, M., Garland, R. M., Wagner, T., Deutschmann, T., and Wahner, A.: MAX-DOAS measurements in Southern China: retrieval of aerosol extinctions and validation using ground-based in-situ data, Atmos. Chem. Phys., 10, 20792089, doi:10.5194/acp-10-2079-2010, 2010.

Liu, X., Cheng, Y., Zhang, Y., Jung, J., Sugimoto, N., Chang, S.Y., Kim, Y. J., Fan, S., and Zeng, L.: Influences of relative humidity and particle chemical composition on aerosol scattering properties during the 2006 PRD campaign, Atmos. Environ., 42, 1525-1536, doi:10.1016/j.atmosenv.2007.10.077, 2008.

Lou, S., Holland, F., Rohrer, F., Lu, K., Bohn, B., Brauers, T., Chang, C. C., Fuchs, H., Häseler, R., Kita, K., Kondo, Y., Li, X., Shao, M., Zeng, L., Wahner, A., Zhang, Y., Wang, W., and Hofzumahaus, A.: Atmospheric $\mathrm{OH}$ reactivities in the Pearl River Delta - China in summer 2006: measurement and model results, Atmos. Chem. Phys., 10, 11243-11260, doi:10.5194/acp-10-11243-2010, 2010.

Lu, K. D., Rohrer, F., Holland, F., Fuchs, H., Bohn, B., Brauers, T., Chang, C. C., Hseler, R., Hu, M., Kita, K., Kondo, Y., Li, X., Lou, S. R., Nehr, S., Shao, M., Zeng, L. M., Wahner, A., Zhang, Y. H., and Hofzumahaus, A.: Observation and modelling of $\mathrm{OH}$ and $\mathrm{HO}_{2}$ concentrations in the Pearl River Delta 2006: a missing $\mathrm{OH}$ source in a VOC rich atmosphere, Atmos. Chem. Phys. Discuss., 11, 11311-11378, doi:10.5194/acpd-11-113112011, 2011.

Qin, M., Xie, P., Su, H., Gu, J., Peng, F., Li, S., Zeng, L., Liu, J., Liu, W., and Zhang, Y.: An observational study of the $\mathrm{HONO}-\mathrm{NO}_{2}$ coupling at an urban site in Guangzhou City, South China, Atmos. Environ., 43, 5731-5742, doi:10.1016/j.atmosenv.2009.08.017, 2009.

Ren, X., Gao, H., Zhou, X., Crounse, J. D., Wennberg, P. O., Browne, E. C., LaFranchi, B. W., Cohen, R. C., McKay, M., Goldstein, A. H., and Mao, J.: Measurement of atmospheric nitrous acid at Bodgett Forest during BEARPEX2007, Atmos. Chem. Phys., 10, 6283-6294, doi:10.5194/acp-10-6283-2010, 2010.

Richter, A., Burrows, J. P., Nusz, H., Granier, C., and Niemeier, U.: Increase in tropospheric nitrogen dioxide over China observed from space, Nature, 437, 129-132, doi:10.1038/nature04092, 2005.

Rohrer, F., Bohn, B., Brauers, T., Brüning, D., Johnen, F.-J., Wahner, A., and Kleffmann, J.: Characterisation of the photolytic HONO-source in the atmosphere simulation chamber SAPHIR, Atmos. Chem. Phys., 5, 2189-2201, doi:10.5194/acp-5-21892005, 2005.

Shon, Z. H., Lee, G., Song, S. K., Lee, M., Han, J., and Lee, D.: Characteristics of reactive nitrogen compounds and other relevant trace gases in the atmosphere at urban and rural areas of Korea during May-June, 2004, J. Atmos. Chem., 58, 203-218, doi:10.1007/s10874-007-9088-4, 2007.
Song, C. H., Park, M. E., Lee, E. J., Lee, J. H., Lee, B. K., Lee, D. S., Kim, J., Han, J. S., Moon, K. J., and Kondo, Y.: Possible particulate nitrite formation and its atmospheric implications inferred from the observations in Seoul, Korea, Atmos. Environ., 43, 2168-2173, doi:10.1016/j.atmosenv.2009.01.018, 2009.

Sörgel, M., Regelin, E., Bozem, H., Diesch, J.-M., Drewnick, F., Fischer, H., Harder, H., Held, A., Hosaynali-Beygi, Z., Martinez, M., and Zetzsch, C.: Quantification of the unknown HONO daytime source and its relation to $\mathrm{NO}_{2}$, Atmos. Chem. Phys., 11, 10433-10447, doi:10.5194/acp-11-10433-2011, $2011 \mathrm{a}$.

Sörgel, M., Trebs, I., Serafimovich, A., Moravek, A., Held, A., and Zetzsch, C.: Simultaneous HONO measurements in and above a forest canopy: influence of turbulent exchange on mixing ratio differences, Atmos. Chem. Phys., 11, 841-855, doi:10.5194/acp11-841-2011, 2011 b.

Spindler, G., Brüggemann, E., and Herrmann, H.: Nitrous acid concentration measurements and estimation of dry deposition over grassland in Eastern Germany, in: Proceedings of the EUROTRAC Symposium 1998, Vol. 2, WITpress, Southampton, UK, 218-222, 1999.

Stemmler, K., Ammann, M., Donders, C., Kleffmann, J., and George, C.: Photosensitized reduction of nitrogen dioxide on humic acid as a source of nitrous acid, Nature, 440, 195-198, doi:10.1038/nature04603, 2006.

Stemmler, K., Ndour, M., Elshorbany, Y., Kleffmann, J., D’Anna, B., George, C., Bohn, B., and Ammann, M.: Light induced conversion of nitrogen dioxide into nitrous acid on submicron humic acid aerosol, Atmos. Chem. Phys., 7, 4237-4248, doi:10.5194/acp-7-4237-2007, 2007.

Stutz, J., Alicke, B., and Neftel, A.: Nitrous acid formation in the urban atmosphere: gradient measurements of $\mathrm{NO}_{2}$ and HONO over grass in Milan, Italy, J. Geophys. Res., 107, 8192, doi:10.1029/2001jd000390, 2002.

Stutz, J., Alicke, B., Ackermann, R., Geyer, A., Wang, S., White, A. B., Williams, E. J., Spicer, C. W., and Fast, J. D.: Relative humidity dependence of HONO chemistry in urban areas, J. Geophys. Res., 109, D03307, doi:10.1029/2003jd004135, 2004.

Su, H., Cheng, Y. F., Cheng, P., Zhang, Y. H., Dong, S., Zeng, L. M., Wang, X., Slanina, J., Shao, M., and Wiedensohler, A.: Observation of nighttime nitrous acid (HONO) formation at a nonurban site during PRIDE-PRD2004 in China, Atmos. Environ., 42, 6219-6232, doi:10.1016/j.atmosenv.2008.04.006, 2008a.

Su, H., Cheng, Y. F., Shao, M., Gao, D. F., Yu, Z. Y., Zeng, L. M., Slanina, J., Zhang, Y. H., and Wiedensohler, A.: Nitrous acid (HONO) and its daytime sources at a rural site during the 2004 PRIDE-PRD experiment in China, J. Geophys. Res., 113, D14312, doi:10.1029/2007jd009060, 2008b.

Su, H., Cheng, Y., Oswald, R., Behrendt, T., Trebs, I., Meixner, F. X., Andreae, M. O., Cheng, P., Zhang, Y., and Pöschl, U.: Soil Nitrite as a Source of Atmospheric HONO and OH Radicals, Science, 333, 1616-1618, doi:10.1126/science.1207687, 2011.

Takegawa, N., Miyakawa, T., Kondo, Y., Jimenez, J. L., Zhang, Q., Worsnop, D. R., and Fukuda, M.: Seasonal and diurnal variations of submicron organic aerosol in Tokyo observed using the Aerodyne aerosol mass spectrometer, J. Geophys. Res., 111, D11206, doi:10.1029/2005jd006515, 2006.

Trick, S.: Formation of nitrous acid on urban surfaces, Ph.D. thesis, Universität Heidelberg, Heidelberg, Germany, 2004. 
Wong, K. W., Oh, H.-J., Lefer, B. L., Rappenglück, B., and Stutz, J.: Vertical profiles of nitrous acid in the nocturnal urban atmosphere of Houston, TX, Atmos. Chem. Phys., 11, 3595-3609, doi:10.5194/acp-11-3595-2011, 2011.

Wong, K. W., Tsai, C., Lefer, B., Haman, C., Grossberg, N., Brune, W. H., Ren, X., Luke, W., and Stutz, J.: Daytime HONO Vertical gradients during SHARP 2009 in Houston, TX, Atmos. Chem. Phys., 12, 635-652, doi:10.5194/acp-12-635-2012, 2012.

Yang, Q., Su, H., Brauers, T., Cheng, Y. F., Gu, J., Häseler, R., Hofzumahaus, A., Hu, M., Li, X., Lu, K., Wiedensohler, A., Zeng, L., Zhu, T., Wahner, A., and Zhang, Y.: Daytime Nitrous Acid (HONO) Formation in the Megacity Beijing, Atmos. Chem. Phys. Discuss., in preparation, 2010.

Yu, Y., Galle, B., Panday, A., Hodson, E., Prinn, R., and Wang, S.: Observations of high rates of $\mathrm{NO}_{2}$-HONO conversion in the nocturnal atmospheric boundary layer in Kathmandu, Nepal, Atmos. Chem. Phys., 9, 6401-6415, doi:10.5194/acp-9-6401-2009, 2009.

Yue, D. L., Hu, M., Wu, Z. J., Guo, S., Wen, M. T., Nowak, A., Wehner, B., Wiedensohler, A., Takegawa, N., Kondo, Y., Wang, X. S., Li, Y. P., Zeng, L. M., and Zhang, Y. H.: Variation of particle number size distributions and chemical compositions at the urban and downwind regional sites in the Pearl River Delta during summertime pollution episodes, Atmos. Chem. Phys., 10, 9431-9439, doi:10.5194/acp-10-9431-2010, 2010.
Zhang, B. and Tao, F.-M.: Direct homogeneous nucleation of $\mathrm{NO}_{2}, \mathrm{H}_{2} \mathrm{O}$, and $\mathrm{NH}_{3}$ for the production of ammonium nitrate particles and HONO gas, Chem. Phys. Lett., 489, 143-147, doi:10.1016/j.cplett.2010.02.059, 2010.

Zhang, Y. H., Hu, M., M., S., Brauers, T., Chang, C. C., Hofzumahaus, A., Holland, F., Li, X., Lu, K., Kondo, Y., Nowak, A., Pöschl, U., Rohrer, F., Zeng, L., Wiedensohler, A., and Wahner, A.: Continuous efforts to investigate regional air pollution in the Pearl River Delta, China: PRIDE-PRD2006 campaign, Atmos. Chem. Phys., in preparation, 2012.

Zhou, X., He, Y., Huang, G., Thornberry, T. D., Carroll, M. A., and Bertman, S. B.: Photochemical production of nitrous acid on glass sample manifold surface, Geophys. Res. Lett., 29, 1681, doi:10.1029/2002g1015080, 2002.

Zhou, X., Gao, H., He, Y., Huang, G., Bertman, S. B., Civerolo, K., and Schwab, J.: Nitric acid photolysis on surfaces in low- $\mathrm{NO}_{\mathrm{X}}$ environments: significant atmospheric implications, Geophys. Res. Lett., 30, 2217, doi:10.1029/2003gl018620, 2003.

Zhou, X., Huang, G., Civerolo, K., Roychowdhury, U., and Demerjian, K. L.: Summertime observations of $\mathrm{HONO}, \mathrm{HCHO}$, and $\mathrm{O}_{3}$ at the summit of Whiteface Mountain, New York, J. Geophys. Res., 112, D08 311, doi:10.1029/2006jd007256, 2007.

Zhou, X. et al.: Nitric acid photolysis on forest canopy surface as a source for tropospheric nitrous acid, Nature Geosci, 4, 440-443, doi:10.1038/ngeo1164, 2011. 